\title{
Fibroblast Growth Factors and their Emerging Cancer-Related Aspects
}

\section{Anibah Khalid ${ }^{1}$ and Muhammad Asim Javaid ${ }^{2 *}$}

${ }^{1}$ Atta-ur-Rehman School of Applied Biosciences, National University of Sciences and Technology, NUST, Islamabad, Pakistan

${ }^{2}$ University of Bedfordshire, University square, Luton, LU1 3JU, UK

\begin{abstract}
Fibroblast growth factors (FGF) are proteins that are involved in several biological and developmental processes. Cell proliferation, cell motility, cell survival, and angiogenesis are the fundamental mechanisms that are carried out by these growth factors. FGF ligands when to interact with their receptors-FGFRs, elicit certain signaling pathways that ultimately lead to precise regulated cellular responses. Alterations in FGF/FGFR signaling results in various types of abnormalities. The transition of normal signaling mode of FGFs/FGFRs to an unusual functional pattern causes neurological disorders, skeletal disorders, tumor progression and tumor neovascularization. Overexpression of FGFs and FGFRs has been correlated with advanced tumor forms, mainly prostate, mammary gland, bladder and renal cell carcinomas. These GFs and their receptors are among the fundamental mediators of tumor angiogenesis, others being VEGF, Ang-1, etc. Many pharmaceutical therapies have evolved in the past years to minimize the effects of FGF/FGFR and VEGF signaling, individually as well as simultaneously. Tyrosine kinase inhibitors are the most prominent compounds that have been investigated exclusively in phase I and II clinical trials. However, the applicability of developing therapeutic techniques needs a further illustration better to comprehend the complexity of the underlying mechanism and to provide patients with a better outcome.
\end{abstract}

Keywords: Fibroblast growth factors; Fibroblast growth factor receptors; Cancer; Tumor growth; Angiogenesis; Biological activities; Vascular endothelial growth factor; Therapeutic inhibitors; Tyrosine kinase inhibitors

Abbreviations: ACTH: Adrenocorticotropic Hormone; Ang: Angiopoietin; BC: Breast Cancer; Bcl-2: B-cell Lymphoma 2; ECM: Extracellular Matrix; EGF: Epidermal Growth Factor; FGF: Fibroblast Growth Factor; FGFR: Fibroblast Growth Factor Receptor; GH: Growth Hormone; hESCs: Human Embryonic Stem Cells; HGF: Hepatocyte Growth Factor; HIF: Hypoxia-Induced Factor; hMSCs: Human Mesenchymal Stem Cells; HPDE: Human Pancreatic Duct Epithelial Cells; HSPG: Heparin Sulfate Proteoglycan; IFN: Interferon; Ig-like: Immunoglobulin-like; IL: Interleukin; LH: Luteinizing Hormone; mAb: Monoclonal Antibody; MAPK: Mitogen-Activated Protein Kinases; MEK: Mitogen-Activated Protein Kinase Kinase i.e. MAPKK; MMPs: Matrix Metalloproteinases; NO: Nitric Oxide; PDGF: Platelet-Derived Growth Factor; PDGFR: Platelet-Derived Growth Factor Receptor; PGE2: Prostaglandin E2; PKC: Protein Kinase C; RTK: Receptor Tyrosine Kinase; TACC1: Transforming, Acidic Coiled-Coil Containing Protein 1; TGF: Transforming Growth Factor; Upa: Urokinase Plasminogen Activator; VEGF: Vascular Endothelial Growth Factor; VEGFR: Vascular Endothelial Growth Factor Receptor; XIAP: X-Linked Inhibitor of Apoptosis Protein.

\section{Introduction}

For years, it was known that the brain and the pituitary glands enclosed some mitogenic agents [1]. In 1973, an entity dissimilar from pituitary hormones was isolated from the bovine pituitary 3T3 fibroblasts. The identified substance was fibroblast growth factor that induced the growth of 3T3 cells [2]. Two different forms of proteins were involved in the growth of $3 \mathrm{~T} 3$ cells. The first one was aFGF (acidic Fibroblast Growth Factor) and the second one was bFGF (basic fibroblast growth factor). aFGF had a 5.6 isoelectric point (pI) (acidic); bFGF had $>9$ pI (basic). bFGF and aFGF share 55\% homology within their sequences. Fibroblast growth factor-1 and Fibroblast growth factor-2 were previously known as aFGF and bFGF, respectively [3]. With the advancing technology and usage of emerging capacities, up to
22 members of the fibroblast growth factor family have been classified in humans (Table 1). Hese22 genes of the FGF family encode proteins that share about 25 to 55 percent sequence similarity within the core region (120-130 aa) [4]. Among the 22 members of the FGF family, 4 of them (Fibroblast growth factor -11, -12, -13, -14) although show high sequence homology with prototypic FGFs, however, are unable to activate the FGFRs and are therefore not employed as FGFs. Instead, they have been entitled as Fibroblast homologous factors-FHFs. Whereas FGF-19 (human) is orthologous to FGF-15 (mouse) [5].

The members of the fibroblast growth factor family are involved in diverse biological activities such as wound healing, MAPK cascade, angiogenesis, cell differentiation, cell growth and proliferation, axon guidance, neuron development, etc. FGFs are localized within the nucleus and cytoplasm (cytosol) whereas some of them function in the extracellular space. Other members, for instance, bFGF, get accumulated in the extracellular matrix and are activated by other factors [6-9]. The FGF ligands interact with their specific receptors, i.e. fibroblast growth factor receptors (FGFRs) leading to the activation of the intracellular signaling cascade [10]. The FGFRs are tyrosine kinase receptors, encoded by four genes i.e. fgfr- 1 , fgfr- 2 , fgfr- 3 and fgfr- 4 [11]. These receptors, upon interaction with FGFs, form complexes with their ligands and Heparin sulfate proteoglycans (HSPGs), undergo dimerization to initiate pathways that ultimately promotes the stimulation physiological and developmental processes. Genetic modifications within the FGF family or irregularities in the processes carried out by FGFs provoke several disorders of nervous system,

*Corresponding authors: Javaid MA, University of Bedfordshire, university square, Luton, LU1 3JU, UK, Tel: +44 (0)1234 400 400; E-mail: asimtarar@gmail.com

Received June 22, 2016; Accepted July 28, 2016; Published July 30, 2016

Citation: Khalid A, Javaid MA (2016) Fibroblast Growth Factors and their Emerging Cancer-Related Aspects. J Cancer Sci Ther 8: 190-205. doi:10.4172/19485956.1000413

Copyright: (C 2016 Khalid A, et al. This is an open-access article distributed under the terms of the Creative Commons Attribution License, which permits unrestricted use, distribution, and reproduction in any medium, provided the original author and source are credited. 
Citation: Khalid A, Javaid MA (2016) Fibroblast Growth Factors and their Emerging Cancer-Related Aspects. J Cancer Sci Ther 8: 190-205. doi:10.4172/1948-5956.1000413

\begin{tabular}{|c|c|c|c|c|c|c|c|}
\hline $\begin{array}{c}\text { Fibroblast } \\
\text { growth factor }\end{array}$ & Gene & Location & $\begin{array}{l}\text { Sequence } \\
\text { length }\end{array}$ & $\begin{array}{l}\text { Subcellular } \\
\text { localization }\end{array}$ & Biological processes & Diseases & Other names \\
\hline $\begin{array}{c}\text { Fibroblast } \\
\text { growth factor } 1\end{array}$ & FGF1 & $5 q 31$ & 155 & $\begin{array}{l}\text { Secreted, } \\
\text { Cytoplasm, } \\
\text { Nucleus }\end{array}$ & $\begin{array}{c}\text { Angiogenesis, innate } \\
\text { immune response, MAPK } \\
\text { cascade, etc. }\end{array}$ & $\begin{array}{l}\text { Familial glomangiom, blount's } \\
\text { disease }\end{array}$ & $\begin{array}{l}\text { Acidic fibroblast growth factor; } \\
\text { aFGF, Endothelial cell growth } \\
\text { factor; ECFG, Heparin-binding } \\
\text { growth factor; HBGF-1. }\end{array}$ \\
\hline $\begin{array}{c}\text { Fibroblast } \\
\text { growth factor } 2\end{array}$ & FGF2 & $4 q 26-27$ & 288 & $\begin{array}{l}\text { Secreted, } \\
\text { Nucleus }\end{array}$ & $\begin{array}{c}\text { MAPK cascade, regulation } \\
\text { of angiogenesis, wound } \\
\text { healing, etc. }\end{array}$ & $\begin{array}{c}\text { Rheumatoid arthritis, Eye } \\
\text { neovascular diseases, } \\
\text { Neurodegenerative diseases, etc. }\end{array}$ & $\begin{array}{l}\text { Basic fibroblast growth factor; } \\
\text { bFGF, Heparin-binding growth } \\
\text { factor } 2 \text {; HBGF-2. }\end{array}$ \\
\hline $\begin{array}{c}\text { Fibroblast } \\
\text { growth factor } 3\end{array}$ & FGF3 & $11 q 13$ & 239 & Secreted & $\begin{array}{c}\text { Axon guidance, cell } \\
\text { signaling, organ induction, } \\
\text { etc. }\end{array}$ & $\begin{array}{l}\text { Deafness with labyrinthine } \\
\text { aplasia, microtia, and } \\
\text { microdontia (LAMM) }\end{array}$ & $\begin{array}{l}\text { Heparin-binding growth factor 3; } \\
\text { HBGF-3, Proto-oncogene Int-2 }\end{array}$ \\
\hline $\begin{array}{c}\text { Fibroblast } \\
\text { growth factor } 4\end{array}$ & FGF4 & $11 \mathrm{q} 13.3$ & 206 & Secreted & $\begin{array}{c}\text { Cell signaling, chondroblast } \\
\text { differentiation, etc. }\end{array}$ & $\begin{array}{c}\text { Teratocarcinoma, embryonal } \\
\text { cancer }\end{array}$ & $\begin{array}{c}\text { Heparin secretory -transforming } \\
\text { protein 1; HSTF-1, Heparin-binding } \\
\text { growth factor } 4 \text {; HBGF-4, } \\
\text { Transforming protein KS3 }\end{array}$ \\
\hline $\begin{array}{c}\text { Fibroblast } \\
\text { growth factor } 5\end{array}$ & FGF5 & $4 q 21$ & 268 & Secreted & $\begin{array}{l}\text { Positive regulation of cell } \\
\text { proliferation, Ras protein } \\
\text { signal transduction, etc. }\end{array}$ & Trichomegaly & $\begin{array}{l}\text { Heparin-binding growth factor } 5 \text {; } \\
\text { HBGF-5, Smag-82 }\end{array}$ \\
\hline $\begin{array}{c}\text { Fibroblast } \\
\text { growth factor } 6\end{array}$ & FGF6 & $12 \mathrm{p} 13$ & 208 & $\begin{array}{l}\text { Secreted; } \\
\text { extracellular } \\
\text { space }\end{array}$ & $\begin{array}{l}\text { Cartilage condensation, } \\
\text { signal transduction, etc. }\end{array}$ & Apert syndrome, breast cancer & $\begin{array}{c}\text { Heparin secretory-transforming } \\
\text { protein 2; HSTF-2, Heparin-binding } \\
\text { growth factor 6; HBGF-6 }\end{array}$ \\
\hline $\begin{array}{c}\text { Fibroblast } \\
\text { growth factor } 7\end{array}$ & FGF7 & $15 q 15-21.1$ & 194 & Secreted & $\begin{array}{l}\text { EGFR signaling pathway, } \\
\text { epidermis development, etc. }\end{array}$ & $\begin{array}{l}\text { Bazex syndrome, familial } \\
\text { progressive hyperpigmentation }\end{array}$ & $\begin{array}{l}\text { Heparin-binding growth factor } 7 \text {; } \\
\text { HBGF-7, Keratinocyte growth factor }\end{array}$ \\
\hline $\begin{array}{c}\text { Fibroblast } \\
\text { growth factor } 8\end{array}$ & FGF8 & $10 q 24$ & 233 & Secreted & $\begin{array}{l}\text { Structural morphogenesis, } \\
\text { aorta morphogenesis, } \\
\text { apoptotic process, etc. }\end{array}$ & $\begin{array}{l}\text { Hypogonadotropic } \\
\text { hypogonadism } 6\end{array}$ & $\begin{array}{l}\text { Androgen-induced growth factor; } \\
\text { AIGF, Heparin-binding growth factor } \\
\text { 8; HBGF-8 }\end{array}$ \\
\hline $\begin{array}{c}\text { Fibroblast } \\
\text { growth factor } 9\end{array}$ & FGF9 & $13 q 11-q 12$ & 208 & Secreted & $\begin{array}{l}\text { Angiogenesis, axon } \\
\text { guidance, cell-cell } \\
\text { signaling, etc. }\end{array}$ & Multiple synostoses syndrome 3 & $\begin{array}{c}\text { Glia-activating factor - GAF, } \\
\text { Heparin-binding growth factor } 9 \text {; } \\
\text { HBGF-9 }\end{array}$ \\
\hline $\begin{array}{c}\text { Fibroblast } \\
\text { growth factor } \\
10\end{array}$ & FGF10 & $5 p 12-p 13$ & 208 & Secreted & $\begin{array}{l}\text { Actin cytoskeleton } \\
\text { reorganization, activation } \\
\text { of MAPK activity, thymus } \\
\text { development, etc. }\end{array}$ & $\begin{array}{l}\text { Lacrimo-auriculo-dento-digital } \\
\text { syndrome, Aplasia of lacrimal } \\
\text { and salivary glands (ALSG) }\end{array}$ & Keratinocyte growth factor 2 \\
\hline $\begin{array}{c}\text { Fibroblast } \\
\text { growth factor } \\
11\end{array}$ & FGF11 & $17 p 13.1$ & 225 & $\begin{array}{l}\text { Extracellular } \\
\text { region }\end{array}$ & $\begin{array}{l}\text { Cell-cell signaling, } \\
\text { nervous system } \\
\text { development, signal } \\
\text { transduction, etc. }\end{array}$ & - & $\begin{array}{l}\text { Fibroblast growth factor } \\
\text { homologous factor 3; FHF-3 }\end{array}$ \\
\hline $\begin{array}{c}\text { Fibroblast } \\
\text { growth factor } \\
12\end{array}$ & FGF12 & $3 q 28$ & 243 & Nucleus & $\begin{array}{c}\text { nervous system } \\
\text { development, neuromuscular } \\
\text { process, etc. }\end{array}$ & Brugada syndrome & $\begin{array}{l}\text { Fibroblast growth factor } \\
\text { homologous factor } 1 ; \text { FHF-1, } \\
\text { Myocyte-activating factor }\end{array}$ \\
\hline $\begin{array}{c}\text { Fibroblast } \\
\text { growth factor } \\
13\end{array}$ & FGF13 & Xq26 & 245 & $\begin{array}{l}\text { Cell projection, } \\
\text { Nucleus, } \\
\text { Cytoplasm }\end{array}$ & $\begin{array}{c}\text { Cerebral cortex cell } \\
\text { migration, establishment of } \\
\text { neuroblast polarity, etc. }\end{array}$ & $\begin{array}{l}\text { Wildervanck syndrome, } \\
\text { borjeson-forssman-lehmann } \\
\text { syndrome }\end{array}$ & $\begin{array}{l}\text { Fibroblast growth factor } \\
\text { homologous factor 2; FHF-2 }\end{array}$ \\
\hline $\begin{array}{c}\text { Fibroblast } \\
\text { growth factor } \\
14\end{array}$ & FGF14 & $13 q 34$ & 247 & Nucleus & $\begin{array}{c}\text { Regulation of postsynaptic } \\
\text { membrane potential and } \\
\text { synaptic plasticity, etc. }\end{array}$ & Spinocerebellar ataxia 27 & $\begin{array}{l}\text { Fibroblast growth factor } \\
\text { homologous factor } 4 ; \text { FHF-4 }\end{array}$ \\
\hline $\begin{array}{c}\text { Fibroblast } \\
\text { growth factor } \\
16\end{array}$ & FGF16 & Xq16 & 207 & Secreted & $\begin{array}{c}\text { Metabolic process, } \\
\text { neurotrophin TRK receptor } \\
\text { signaling pathway, etc. }\end{array}$ & Metacarpal 4-5 fusion (MF4) & - \\
\hline $\begin{array}{c}\text { Fibroblast } \\
\text { growth factor } \\
17\end{array}$ & FGF17 & $8 p 21$ & 216 & Secreted & $\begin{array}{l}\text { fGFR signaling pathway, } \\
\text { innate immune response, } \\
\text { IR signaling pathway, etc. }\end{array}$ & $\begin{array}{c}\text { Hypogonadotropic } \\
\text { hypogonadism } 20 \text { with or without } \\
\text { anosmia }(\mathrm{HH} 20)\end{array}$ & - \\
\hline $\begin{array}{c}\text { Fibroblast } \\
\text { growth factor } \\
18\end{array}$ & FGF18 & $5 q 34$ & 207 & Secreted & $\begin{array}{l}\text { Angiogenesis, axon } \\
\text { guidance, cell-cell } \\
\text { signaling, etc. }\end{array}$ & Congenital diaphragmatic hernia & zFGF5 \\
\hline $\begin{array}{c}\text { Fibroblast } \\
\text { growth factor } \\
19\end{array}$ & FGF19 & $11 q 13.1$ & 216 & Secreted & $\begin{array}{c}\text { Positive regulation of } \\
\text { ERK1, ERK2, JNK cascade } \\
\text { and glucose import, etc. }\end{array}$ & Primary Biliary Cirrhosis & - \\
\hline $\begin{array}{c}\text { Fibroblast } \\
\text { growth factor } 20\end{array}$ & FGF20 & 8p21.3-p22 & 211 & Secreted & $\begin{array}{l}\text { Fc-epsilon and FGF receptor } \\
\text { signaling pathway, etc. }\end{array}$ & $\begin{array}{c}\text { Renal hypodysplasia/aplasia } 2 \\
\text { (RHDA2) }\end{array}$ & - \\
\hline $\begin{array}{c}\text { Fibroblast } \\
\text { growth factor } \\
21\end{array}$ & FGF21 & $\begin{array}{l}19 q 13.1- \\
\text { qter }\end{array}$ & 209 & Secreted & $\begin{array}{l}\text { Positive regulation of cell } \\
\text { proliferation and ERK } 1 / 2 \\
\text { cascade, etc. }\end{array}$ & $\begin{array}{l}\text { Renal hypodysplasia/aplasia } 1 \\
\text { and 2, Parkinson's disease }\end{array}$ & - \\
\hline $\begin{array}{c}\text { Fibroblast } \\
\text { growth factor } \\
22\end{array}$ & FGF22 & $19 \mathrm{p} 13.3$ & 170 & Secreted & $\begin{array}{l}\text { Ras protein and small } \\
\text { GTPase mediated signal } \\
\text { transduction, etc. }\end{array}$ & Metabolic diseases & - \\
\hline $\begin{array}{c}\text { Fibroblast } \\
\text { growth factor } \\
23\end{array}$ & FGF23 & $12 \mathrm{p} 13.3$ & 251 & Secreted & $\begin{array}{l}\text { Response to Mg ion and } \\
\text { sodium phosphate, Vit D } \\
\text { catabolic process, etc. }\end{array}$ & $\begin{array}{c}\text { Hypophosphatemic rickets } \\
\text { autosomal dominant } \\
\text { (ADHR), Tumoral calcinosis } \\
\text { hyperphosphatemic familial (HFTC) }\end{array}$ & $\begin{array}{c}\text { Phosphatonin, Tumor-derived } \\
\text { hypophosphatemia-inducing factor }\end{array}$ \\
\hline
\end{tabular}

Table 1: Members of Fibroblast Growth Factor Family (Homo sapiens). The information mentioned above is to the widely expressed fibroblast growth factors, their genes, chromosomal locations along with their sequence lengths, cellular localization. FGFs are concerned with several biological activities and diseases [18]. 
renal system, defects in embryonic development, tumor proliferation and cancer metastasis (Table 1). FGFs have been related to several types of tumors and cancers in association with vascular endothelial growth factor (VEGF) where these growth factors operate to carry out angiogenesis [12-14]. Some of the FGFs are secreted into the extracellular environment while others function intracellularly. All fibroblast growth factors were known to function through paracrine signaling, but advancements in the recent years lead to the affirmation of FGF- 19, 21 and -23 as endocrine signaling molecules [15-18].

This article reviews data about the fibroblast growth factors, their receptors, and signaling pathways, structure and their biological roles, participation in cancer as well therapeutic and pharmacological implications of FGFs. Several studies have been conducted in the past to elucidate the various features of the FGF family. Using X-ray crystallography, NMR and other peculiar techniques, characteristic like 3D structure, domain structure, sequences, cell surface receptor complexes, expression, pathology, etc. have been exquisitely outlined in the literature.

\section{Fibroblast growth factor-FGF family}

The fibroblast growth factor family consists of 22 genes that encode particular proteins, FGFs. The fibroblast growth factor family is composed of related molecules ranging from $17 \mathrm{kDa}$ to $34 \mathrm{kDa}$. The first FGFs to be discovered were aFGF (FGF-1) and the bFGF (FGF-2) from the brain and pituitary extracts of the bovine in the 1970s. In the upcoming years, various other FGFs were identified. Genes of FGF-3, FGF-4, FGF-5 and FGF-6 were isolated as oncogenes [19-21]. FGF-7 is also known as Keratinocytes growth factor and FGF-8 as a growth factor from the carcinoma cells (androgen-induced). FGF-9 was described to be associated with the nervous system and was isolated from glioma cells [22]. Fibroblast growth factors 1 to 9 share a 30-70 percent sequence homology, though these FGFs are of different sizes ranging from 150 to 250 aa [23]. Almost all the members of the FGF family experience ca. 120 similar amino acids i.e. about $16 \%$ to $65 \%$ sequence similarity [24].

The fibroblast growth factor family embodies only 18 FGFR ligands i.e. FGF1-FGF10, FGF16-FGF23. FGF11-FGF14, although share high structural as well as sequence similarity with the other FGF family members but they lack the capacity to activate the FGF receptors and are, thus, more correctly designated as FHFs, i.e. fibroblast homologous factors. Distinct amino acid residues that reside within the receptor binding site of FHFs are responsible for their inability to activate FGFRs. Assembly of FHFs excludes many amino acid residues that are critical for the binding of FHFs to the receptors [25].

On account of phylogeny and sequence similarity, members of the FGF family have been categorized into unique subfamilies account of phylogeny and sequence similarity. This classification includes FGF-1, FGF-4, FGF-7, FGF-9, FGF-8, FGF-11 and FGF-19 subfamilies (Figure 1). Phylogenetic analysis of the FGF subfamily indicates evolutionary and transformative linkages among the members of the gene family. FGFs have also been analyzed by gene chromosomal location to evaluate the evolutionary background of the gene family (Figure 2). This classification results in six subfamilies i.e. FGF1/2/5, FGF7/10/22, FGF3/4/6/19/21/23, FGF9/16/20, FGF11/12/13/14 and FGF8/17/18 subfamilies (Figure 1). Based on closely linked genes sharing similar chromosomal localities members have been assigned to a particular subfamily. For instance, FGF-1, FGF-2, and FGF-5 show close linkage to the Annexin 6, Annexin 5, and Annexin 3 genes, respectively. Therefore, FGF-1, -2 and -5 belong to the same subfamily.

An FGF gene is typically composed of three exons, where exon 1 starts with a Met residue. However, there are some exceptions; for instance, FGF-2 and FGF-3 have particular sequences transcribed at their 5' end [26-27]. In some FGFs, sub-exons are formed when exon 1 passes through the splicing process. Genes of the FGF family are dispersed or clustered (in some cases) throughout the genome. FGF-3, -4 and -19 genes are present on the $11 \mathrm{q} 13$ chromosome, 12 p13 chromosome contains FGF-6 and -23 genes whereas 8p21-p22 chromosome profiles FGF-17 and -20 genes chromosome.

\section{Structure}

The domain structure of FGFs is composed of a core region of about 120 aa -140 aa, containing 28 conserved residues as well as six identical amino acid residues [28]. Among the 28 conserved residues, 10 of them are involved in interactions with the fibroblast growth factor receptors [29]. The homologous core region in most of the FGF members constitutes a cylindrical barrel formed by the precise folding of 12 antiparallel beta strands. Variable amino- and carboxy- terminals that border the core region of FGFs [30]. Exceptions exist in the structure of FGF-1 and FGF-2. These two fibroblast growth factors own a triangular array (allocated within the beta-trefoil structure) formed

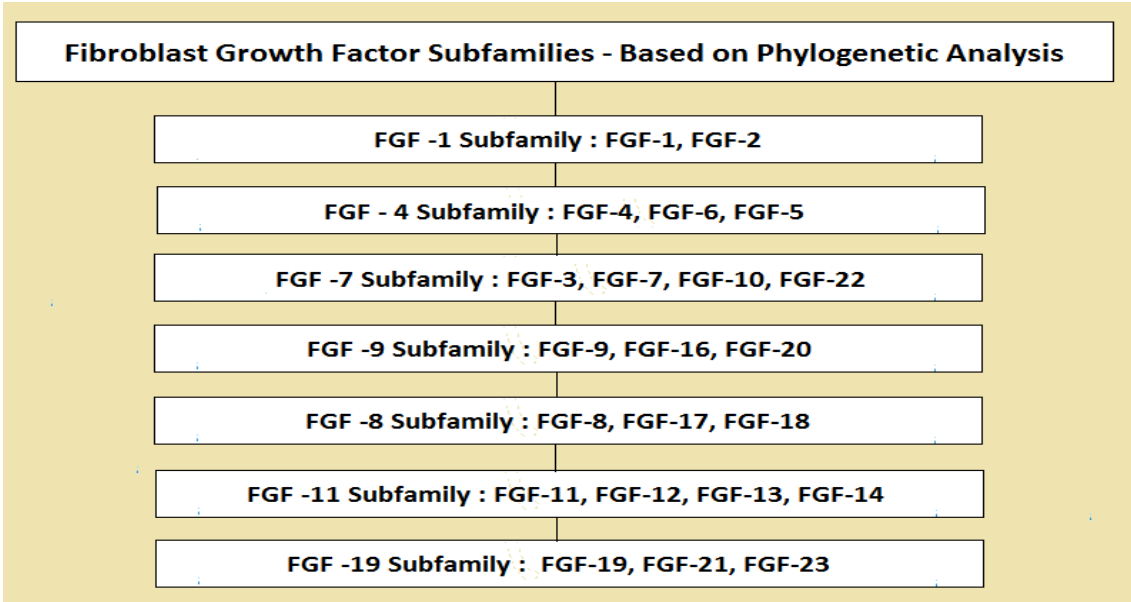

Figure 1: Classification of the fibroblast growth factor (FGF) family based on phylogenetic analysis. Seven subfamilies i.e. FGF-1, FGF-4, FGF-7, FGF-9, FGF-8, FGF11 , and FGF-19, embodies the members of FGF family, mentioned above. 


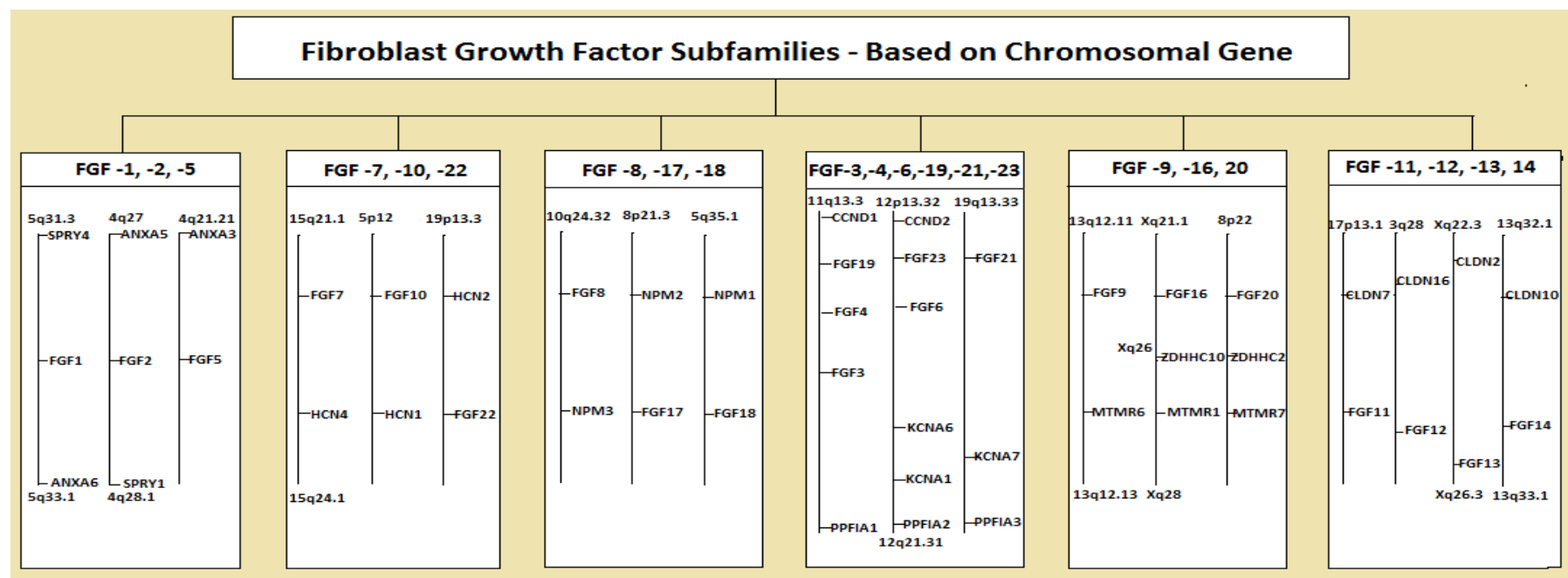

Figure 2: Classification of the FGF superfamily into particular subfamilies based on chromosomal gene analysis (Itoh, Ornitz 2004). The ANXA gene is linked FGF-1, FGF-2, and FGF-5 genes. FGF-7, FGF-10, and FGF-22 are closely related to HCN gene. NPM gene has close linkage with FGF-8, FGF-17, and FGF-18 genes. A single subfamily contains FGF-4, FGF-3, FGF-6, FGF-19, FGF-21 and FGF-23 genes due to their linkage with CCND, PPFIA, and KCNA genes. FGF-9, FGF-16, and FGF-20 are linked to ZDHHC and MTMR gene whereas the FGF homologous factors (FGF11-14) are closely related to CLDN gene.

by a peculiar arrangement of four beta strands [31]. In FGF-2, among the 12 beta strands, two of them i.e. $\beta 10$ and $\beta 11$ possess essential aa residues that are involved in the formation of the primary binding site for heparin. This site is different from the site that interacts and binds with FGFRs [32].

155 aa protein (17-18 kDa) forms FGF-1, which is a nonglycosylated polypeptide that does not possess a distinct signal peptide and is in fact, secreted in the shape of a dimer linked by a disulfide bond and by an ATP-dependent pathway that features synaptotagmin-1 rather than the classical pathway [33]. The domain structure of FGF1 characterizes an NLS-nuclear localization sequence that depicts the involvement of FGF-1 in DNA synthesis. The $18 \mathrm{kDa}$ non-glycosylated protein, FGF-2, is secreted as a monomer and forms four isoforms (22 $\mathrm{kDa}, 22.5 \mathrm{kDa}, 24 \mathrm{kDa}$, and $34 \mathrm{kDa}$ ) based on the presence of different start codons. This growth factor is thought to perform its activities, both intracellularly and extracellularly. Apart from similar domains that FGF-3 shares with other members of the FGF family, it has an NLS motif located at the C-terminal [34]. FGF-4 has two heparin binding sites within its 176 glycoprotein domain structure. FGF-5 is a precursor polypeptide that contains a signal peptide and a mature peptide, 17 aa and 251 aa, respectively. Its unique feature is that it has both types of glycosylation's, i.e. $\mathrm{N}$ - and O- linked. FGF- 6 could be secreted in three precursor isoforms (208, 198 and 175 amino acids) because it contains three different AUG (methionine) start codons. The keratinocyte growth factor, FGF-7, is synthesized as a glycosylated precursor protein that later matures to form the 163 amino acid activated form. The activated form of FGF-7 activity is thought to be hindered by heparin molecules [35]. Three regular exons encode the members of the FGF family. However, in the case of FGF-8, exon one has been split up into four small exons followed by the typical exon 2 and 3. FGF-9 do not own a signal peptide but is secreted adequately, unlike FGF-1 and FGF-2. Known as the keratinocyte growth factor-2, FGF-10 contains a serine-rich motif located at the amino terminal and retains an oddly long signal peptide [36].

FGF-11, also known as FHF-3 (FGF homologous factor-3), maintains an NLS whereas its domain structure has no signal peptide. FGF-12 (FHF-1) possess two NLS sequences (designated as bipartite
NLS) near the amino terminal as well as a typical NLS. FGF-13 (FHF-2) features an amino-terminal alternate splicing. FGF-14 has a secondary signal motif along with a bipartite NLS. FHF-4 lacks the typical signal peptide. FGF-16 and FGF-20 do not have the typical signal sequence, like FGF-9, and are, therefore, secreted like that of FGF-9. Like FGF-8, FGF-17s exon one is also divided into mini exons, leading to several amino terminal isoforms and the other exons i.e. two and three are the same as others. FGF-18 is a secreted glycosylated polypeptide that interacts with heparin molecules whereas FGF-19, FGF-21 and FGF23 lack the heparin binding site within their domain structures [37] (Figure 3).

\section{Fibroblast growth factor receptors}

As a result of either of the two possible mechanisms, several isoforms of the FGF receptors are expressed in humans. A) Expression of various FGF receptor genes or B) expression of particular splice variants that result from the alternative splicing of the same FGF receptor gene. Four genes (fgfr1, fgfr2, fgfr3 and fgfr4) encode these receptors. Seven isoforms of FGF receptors exist due to alternative splicing that occurs within the mRNA of fgfr1, fgfr2, and fgfr3 $[38,39]$. Isoforms include FGFR1b, 1c, FGFR2b, 2c, FGFR3b, 3c, and FGFR4. In some of them, splicing results in the removal of the Ig-I domain and acid box whereas Ig-III alternative splicing results in the formation of type $b$ and $\mathrm{c}$ isoforms. Alternative splicing in Ig-III (carboxyl-terminal half), retains any one of the exons that lie within the domain region. Isoform IIIb (Ig-IIIb) and isoform IIIB results when the splice variant retains exon 8 or exon 9 , respectively (Figure 4). Particular tissue types i.e. epithelial clans express isoform IIIb whereas mesenchymal clans express the isoform IIIc. The various isoforms of the FGF receptors display peculiar specificity and selectivity for different FGF ligands as well as the signal transduction pathway they activate, depending on the type of tissue and the targeted biological activity. The FGF members show increased affinity for particular isoforms. FGF-3, -7, -10, and -22 interacts with isoforms IIIb. Acidic FGF binds with both the isoforms, whereas the other 13 members of the FGF family bind to isoform IIIc [40]. The gene of FGFR4 is exclusive in a sense since no isoforms for this gene exist. 


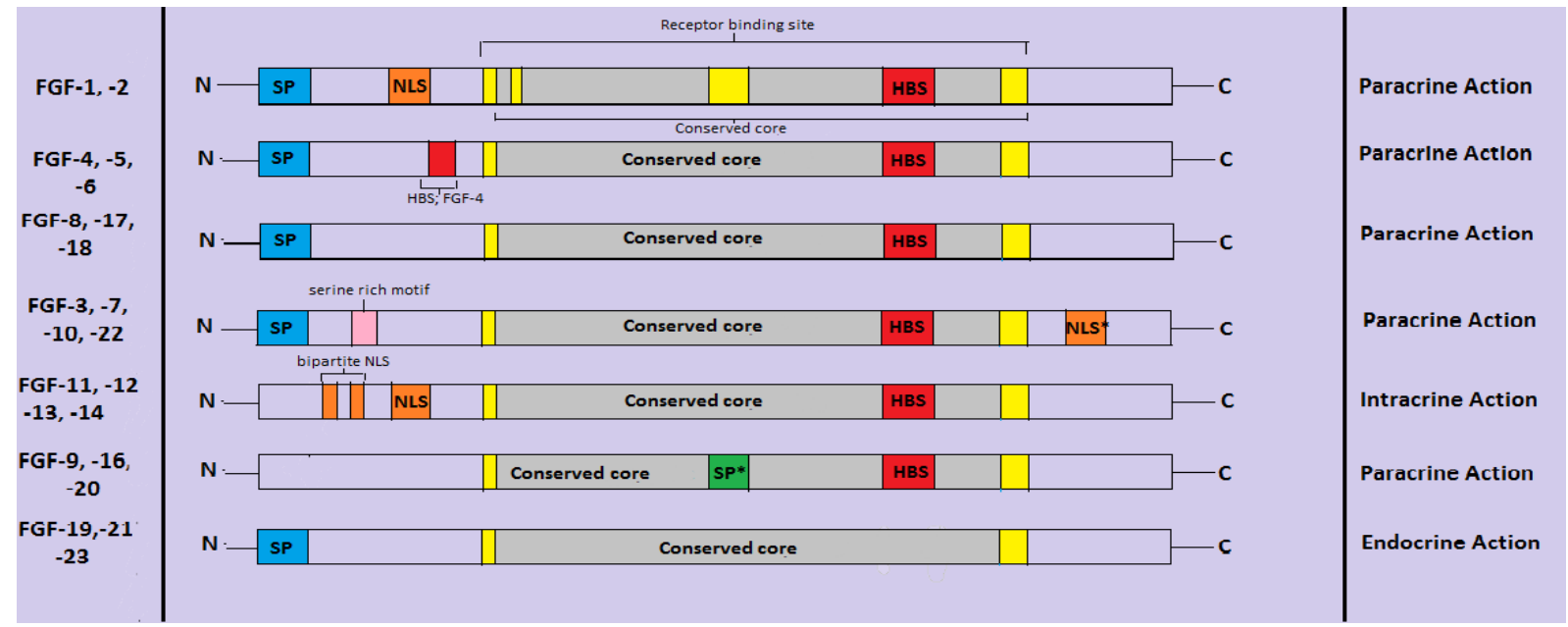

Figure 3: Schematic representation of the domain structure of FGF family [38]. Based on their secretion/action mechanism, the family members have been classified. N; amino terminus, SP; signal peptide/propeptide, NLS; nuclear localization signal, NLS*; nuclear localization signal at C-terminus (FGF-3), HBS; heparin binding site, SP*; uncleaved bipartite signal sequence (secreted), C; carboxy terminus, serine-rich motif (FGF-10), Bipartite NLS (FGF-12/and or FGF-14).

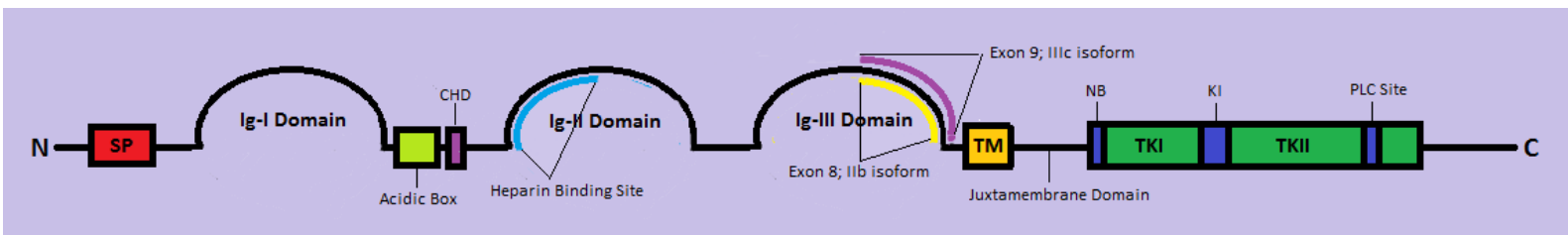

Figure 4: Generalized structure of FGF receptor, displaying ectodomain and an intracellular domain [39,43]. N; amino terminal, three Ig-Like domains, acidic box, CHD; cell adhesion molecule homology domain, Heparin-binding site within Ig-II domain, TM; transmembrane domain, Juxtamembrane domain, NB; nuclear binding domain, $\mathrm{KI}$; kinase insert, found between TKI and TKII i.e. tyrosine kinase subdomains, PLC site (FGFR1)-PLC gamma interacts with this particular site of FGFR1 within the cytoplasmic space, C; carboxy terminal.

\section{Structure and signaling}

The general arrangement of an FGF receptor features an extracellular domain, a transmembrane domain, and a tyrosine kinase cytoplasmic domain. The specific portions of the extracellular domain are a signal peptide followed by three Immunoglobulin-like (Ig-like) domains, designated as Ig-I, Ig-II, and Ig-III. An acid box (serine-rich acidic sequence) is present between Ig-I and Ig-II domains, within the linker region (Figure 4). Ig-I and the acid box might participate in autoinhibition of the receptor itself [41]. Ig-II and Ig-III domains are important for determining ligand specificity and its binding. A heparin molecule that serves as a co-factor assists the functioning of the receptor and increases the efficacy of the receptor-ligand complex. Ig-II domain (166-177 amino acids) contains the receptor interaction site. Alternative splicing within the Ig-III area determines the isoform of FGFR. A juxtamembrane region is present downward the transmembrane portion of the receptor which then leads to the tyrosine kinase-TK domain. A kinase insert of around 14 amino acids divides the TK region into two functional kinases i.e. kinase 1 and kinase 2 or TKI-I and TKI-II. The carboxy-terminal of FGFR1 contains a PLC $\gamma$ interaction site that binds with PLC $\gamma$ within the cytoplasmic region. The CAM homology domain-CHD is involved in the formation of an endosome and nuclear transport of the receptor, FGFR1 [42].

When the FGF ligand binds to the FGF receptor through its secondary receptor binding site, the activated receptor undergoes dimerization. As the ligand approaches its receptor, it interacts with the Ig-II and Ig-III domains of the receptor and forms a complex. The complex is, indeed, a ternary complex since the heparin molecules are also involved in the formation of the compound. A fully operating complex is composed of FGF, FGFR, and Heparin molecules in the ratio of 2:2:2 to form a symmetrically positioned dimer. After the binding of the FGF ligand and the co-factor (heparin molecule), the receptor is activated i.e. dimerized, and the tyrosine kinase domains are now trans-phosphorylated mainly within the A-loop region. Phosphorylation of the cytoplasmic domain region is then extended to the carboxy terminal region, juxtamembrane region and kinase insert region. The PLC gamma site is also phosphorylated, which in turns activates the effector molecules within the cytoplasmic region. The most important signaling cascades that are triggered by the activation of FGFR are the RAS/MAPK pathway, PLC $\gamma$ pathway, and PI3K/ Akt pathway. Heparin molecules or heparin sulfate proteoglycans participate in the formation and arrangement of the FGFR dimer. It functions to stabilize the interactions within the protein structures. In this case, it works to secure the attachment of FGF with the FGF receptor in a 1:1 ratio.

Considering the vast range of activities that FGFs perform within the extracellular environment, many efforts have been made to investigate their structure as well as their particular role in various malignancies and diseases. Due to the rapid evolvement of many cancer types, FGFs have provoked concern as the frontline players of cancer development due to their well-studied roles in directing cell proliferation, angiogenesis, and cell migration. Hence, the modern day research is more focused on finding out the likely job of FGFs and FGFRs in the advancement of individual tumors. In the upcoming section, the role of FGFs and FGFRs in various biological activities, tumor development, and cancer metastases will be discussed. Also, the inhibitors of FGFs/FGFRs used as therapeutic drugs for clinical trials will be reviewed (Figures 4 and 5). 


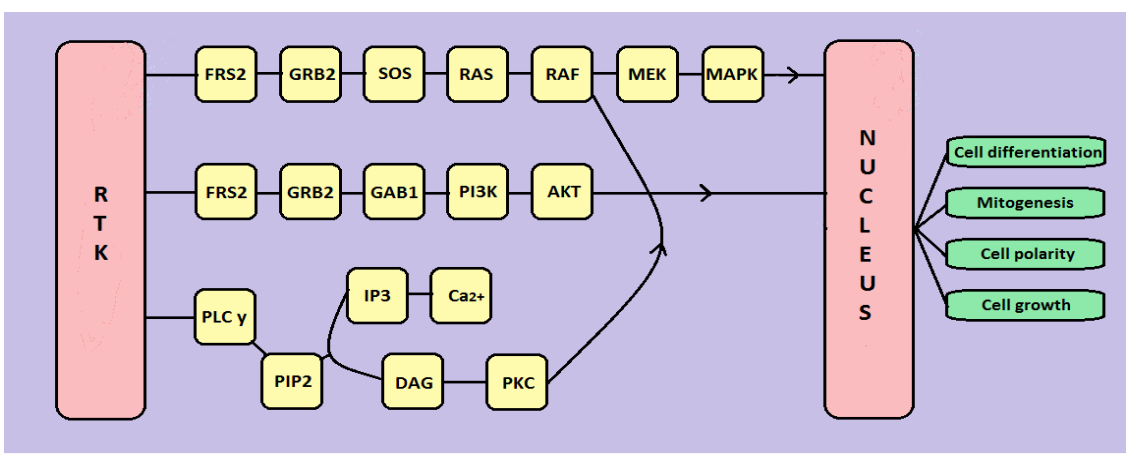

Figure 5: A generalized representation of signaling pathways, mainly activated after the formation of FGF-FGFR-HSPG ternary complex. Phosphorylation of docking protein FRS2 provides distant sites for the activation of secondary proteins within the cytoplasmic region. FRS2 triggers RAS/MAPK and PI3K/Akt pathways, whereas PLC gamma is activated by directly interacting with the PLC Y site located at the carboxy terminal of FGFR. PLC gamma pathway upon activation stimulates several intracellular proteins. Among them, activation of PKC ultimately stimulates the MAPK cascade by phosphorylating RAF (by RAS). As a result of these signaling cascades, various biological processes are brought about, such as determining the polarity of the cell, differentiation, growth, etc.

\section{FGFs and FGFRs: Roles in biological processes}

FGFs and FGFRs function to promote cell proliferation, angiogenesis, cell survival, and cell migration particularly at inflammatory, tumor and other hypoxic sites surrounding the primary tumor region as well as within the normal extracellular environment to carry out normal physiological activities. The signal transduction pathways activated by FGFs are well-characterized and follow specific orders from the guiding proteins within the cellular environment. Eventually, the outcome observed is standardized according to the needs of the surrounding cells and tissues. FGFs carry out cell proliferation in epithelial cells, adipocytes, and endothelial cells [43]. FGF-2 has been reported to raise the cell proliferation rate in MC3T3E1 osteoblast-like cells. When compared with other factors like TGF- $\beta$, PDGF, PGE2, etc., the pace with which FGF-2 increased the cell proliferation was recorded to be the highest [44]. FGF1 and FGF-2 induce cell proliferation in HT-29 cell lines and neuroepithelial cells, respectively $[45,46]$. FGF-7 has been linked with the proliferation of epithelial cells [47]. FGF-10 and FGF-18 have been associated with the cellular proliferation within prostate cancerous cells, osteoblasts, chondrocytes, etc. [48-50].

Members of the FGF family are actively involved in promoting the cellular movement to perform several activities. FGFs function to form well-characterized mesoderm layer by assisting the migration of cells [51]. FGF-2 is involved in the migration of endothelial cells whereas both FGF-1 and -2 induce migratory properties in cochlear ganglion cells $[52,53]$. FGF-7 shows increased migratory properties in HPDE cells as well as in keratinocytes [54,55]. Cardiac cells (neural crest cells) show movement in response to FGF-8 signaling [56]. Angiogenesis and cell differentiation are other activities that FGFs administer along with FGFRs in a directed and well-coordinated manner. FGFs regulate the cell differentiation mechanism of hESCs [57]. FGF-2 promotes the chondrogenic ability of hMSCs [58], whereas FGF-7 and FGF-20 are responsible for the differentiation that occurs in keratinocytes and the conversion of stem cell to dopamine-producing neurons within monkeys, respectively. FGFs have been reported to be responsible for making angiogenesis liable within the standard as well as many cancerous settings. FGF1 and FGF2 are concerned with the occurrence of angiogenesis via endothelial cells [59]. FGF-1 is a known angiogenic factor that triggers angiogenesis within the chorioallantoic membraneCAM of chickens whereas FGF-9 has been described to stimulate angiogenesis during bone repair [60-62].
The functioning of FGFs in the process of wound healing is an intriguing phenomenon and marks another biological activity that is carried out in the presence of these GFs [63]. The conduct of FGFs, particularly that of FGF-1 and -2 , is well-defined in angiogenesis. Angiogenesis leads to the successful accomplishment of the wound healing process. Wound healing requires four phases (inflammation, contraction, repair and regeneration) to reach an outcome [64,65]. Evidently, FGFs have been proven to take part in three out of four phases of wound repairing [66]. These GFs are found in the ECM as well as in the fibroblasts and endothelial cells [67]. Usually, FGFs are thought to be expressed at a particular site as it encounters a wound [68]. Inflammation, the first phase of wound healing, features various members of the FGF family i.e. FGF-1, FGF-4, and FGF-2 [69-71]. These FGFs attract other immune cells to the site of inflammation, control the proliferation of platelets since they have significant activity at inflammation sites [72]. FGFs regulate the division of megakaryocyte progenitor cells at the point of inflammation. Endothelial cells and fibroblasts are present in the second phase of wound healing. These cells express certain FGFs that display their activity in the cellular proliferation of these cells [73]. FGF-2 stimulates the migration of endothelial cells by the activation of uPA (urokinase-type plasminogen activator) [74]. uPA when interacts with its receptor on the cell surface, in turn, converts plasminogen to plasmin that cleaves fibrin, causing fibrinolysis and promoting the movement of endothelial cells [75]. AV $\beta 3$ cell-surface adhesion molecule characterizes another mechanism adopted by FGF-2 to facilitate the movement of endothelial cells. FGF7 plays a role in the final phase, regeneration, of wound healing $[76,77]$. FGFs induce the limb buds to evolve and grow gradually $[78,79]$.

\section{FGF and FGFRs: Roles in cancer}

Various cancers express FGFs-FGFRs at an increased level. The signaling scheme of these growth factors reinforces the survival, growth, and dissemination of tumors. In cancer state, FGFs facilitates the tumors to propagate to secondary locations either by promoting angiogenesis or by guiding other angiogenic factors to bring about their activity. As a result of FGF-FGFR interactions, various cellular elements like transcription factors and secondary proteins are triggered. An orderly working of all these elements is crucial at every step of the cascade and loss of check at any point may lead to uncontrolled cell division and neoplasia $[80,81]$. Tumor cell proliferation marks overexpression of FGFs. These GFs may probably be expressed either by tumor cells or by the stromal cells found in the surrounding environment, in response to a signal received from tumor cells. They operate in a paracrine [82] or an 
autocrine manner $[83,84]$, thereby targeting tumor or the stromal cells. Another possible undercover mechanism behind FGF participation in cancer is their release from the extracellular matrix - ECM [85]. ECM, upon its degradation by MMPs, releases FGFs that are stored or trapped within by MMPs. Otherwise, FGFs may associate with a carrier protein that delivers these FGFs to their respective receptors and in turn activate them [86].

FGFs when overexpressed in the tumor microenvironment, invasive and metastatic properties are gained by the cancer cells. However, the expression of FGF receptors is more discriminatory when it comes to the type of tumor [87]. FGFR1 signaling outlines prostate cancer progression. It's possible due to the overexpression of FGFR1 in basal cells, prostate epithelial cells and prostate progenitor cells that are embodied by the basal prostate gland-benign [88]. The ligands of FGFR1 i.e. FGF-1, 2, 8b and 17, also show increased expression in prostate cancer [89]. Studies concerned with the role of FGFR1 in the progression of prostate cancer have reported that hyperplasia or neoplasia within the prostate epithelium is caused by a continuously activated form of FGFR1 [90]. Another study revealed the possible cause of transition of non-malignant prostate cancer cells to the malignant phenotype. The shift of FGFR2 splice forms, IIIb to IIIc is concerned with the underlying mechanism behind the proliferation of prostate epithelial cells. As mentioned earlier, the expression of IIIb and IIIc isoforms are characterized by epithelial and mesenchymal cells, respectively. Furthermore, FGF-2, IIIc ligand, was also overexpressed indicating its role along with that of IIIc isoform in the epithelial cell division. Hence, the conversion of non-invasive epithelial cells to the malignant phenotype [91] is due to the switch that ensures the FGFR2 signaling through the IIIc isoform (expressed by mesenchymal cells and hence has the potency to invade surrounding tissues) rather than the IIIb isoform. FGFR2-IIIb isoform has also been described to possess repressive tumor properties. Therefore, the $f g f r 2-$ $I I I b$ gene might be viewed as a tumor suppressor gene [92]. However, further research is required to enlighten the mechanism that underlies the functioning of FGFR2-IIIb isoform [93].

Fibroblast growth factors are related to mammary gland carcinogenesis. Studies have confirmed that mammary oncogene families sometimes operate in cooperation with each other for the successful tumorigenesis of the mammary gland. Wnt1 was the first oncogene to be identified that was activated by MMTV [94]. Shortly after its discovery, $f g f 3$ oncogene was located at a separate locus. Subsequent selection of oncogenes for induction of mammary tumor development within the MMTV infected mice, correlated wnt1 and $f g f 3$ genes [95].The link between FGFs and breast cancer aroused the probability to look for the particularities of the oncogenes mentioned above. During the RNA analysis of $f g f 3$ and $f g f 4$ oncogenes, their particular role in the mammary tumor DNA amplification was not establishment on an authentic ground. However, the CCND1 oncogene that lies close to the $f g f 3 / 4$ genes on chromosome $11 q$ was later found to be the active oncogene within the region. Indeed, $f g f 3 / 4$ genes were being transcribed as mere "riders" of the amplicon containing the oncogene concerned with the disease $[96,97]$. Moreover, roles of FGF$1,-2$, and -8 have also been described in assorted types of breast cancers [98-100]. FGF receptors, on the other hand, have been associated with breast carcinogenesis. For instance, FGFR1, FGFR4 have been detected to be overexpressed in some types of BCs, studies report [101,102]. FGFs serve as special players of certain carcinogenesis process due to their cell proliferating, anti-apoptotic and angiogenic properties. FGFs and FGFRs participate in skin [103] and urothelial carcinogenesis [104]. The MAPK pathway which is triggered by activation of FGFR1 has been related to the proliferation of tumor cells [105]. This path indicates the role of Ras that is can be activated by two separate proteins, in the activation of MAPK. FRS2 [106] and Shc-src homology 2 containing protein [107]. Proliferating cells express both of these proteins. However, the mechanisms by which these proteins work is entirely different from one another,

Point mutations, genetic alterations, alternative splicing that results in various splice variants and abnormal expression of FGFs and FGFRs have the potential to form cancer [108]. Point mutations have the least connectivity with the disease advancement in humans. However, a point mutation in three out of four FGFRs i.e. FGFR1, 2 and 3, has been linked to several skeletal disorders. Genetic alterations that modify the arrangement of the genes leads to the synthesis of a different form of protein that does not function properly. For instance, the FGFR2 receptor in osteosarcoma cell line of rats is continuously activated, even in the absence of a ligand [109]. Continuous activation of FGFR2 is due to a rearrangement that takes places within the carboxy-terminal region of the receptor. Other than this, overexpression of FGFR1 and FGFR2 has been reported in renal cell carcinoma [110]. FGFR2 is overexpressed in breast cancer and gastric cancer [111,112]. Human myeloid cells, bladder carcinoma as well as urinary tract carcinomas overexpress FGFR3 [113-115]. Alternative splicing, on the other end, creates such variants that do not hold back their ability to help survive the tumor environment, facilitating its cells through various signal transduction pathways by devising desired results. Splice variants of FGFR2 are linked to the type of breast cancer. FGFRs variants have also been associated with ovarian cancer, prostate cancer, etc. [116,117].

Low-grade urothelial bladder carcinomas are reported to have FGFR3 mutations $[118,119]$. Glioblastoma is a type of brain tumor in adults. A subgroup of this tumor type has been described to be caused due to a fusion protein, mainly involving the tyrosine kinase domain of FGFR1 or 3 that has been fused with the TACC1 or 3 encoding regions $[120,121]$. FGFR3-TACC3 fusion proteins have been associated with bladder cancer, cervical cancer [122,123]. Other examples include overexpression of FGFR2-TACC3 in cholangiocarcinomas (CCAa). FGF receptor 2, on the other hand, has been illustrated to undergo mutation in cervical, endometrial and squamous cell lung cancer [124-126]. Missense mutations of FGFR2 can also occur in gastric and ovarian cancer [127,128]. Polymorphism of FGFR2 can be related to breast carcinoma, and the isoform FGFR2-IIIc polymorphism has been outlined in breast cancer (BC) caused by a BRCA2 mutation. An aggressive form of breast cancer has been correlated with FGFR3 overexpression [129] and another form of breast cancer malignancy has been associated with FGFR1. Squamous cell lung cancer and NSCLC is related to FGFR1 amplification or other less defined mechanisms [130,131]. A study featuring Caucasian males demonstrated FGFR4 allele Arg-388 mutation with an aggressive form of prostate carcinoma [132].

Fibroblast growth factors act as mitogenic agents thus compelling the cells to undergo division. They may also act as anti-apoptotic agents thereby supporting cell survival pathways. FGFs carry out their roles in cancer by acting as any of the agents mentioned above. FGF-1 and FGF2 are known potent mitogenic agents [133]. The other FGFs such as FGF- $3,-4$ and -5 have also been related to maintaining the proliferative properties of individual cancer cells lines $[134,135]$. Cell survival by anti-apoptotic mechanism is, indeed, an alluring process that assists the tumor cells to escape the body defense attacks and in turn, show resistance to different therapeutic agents. FGF-2 has been depicted to govern various anti-apoptotic proteins, such as Bcl-2 and XIAP, 
within the cellular environment [136,137]. On the other hand, FGF-2 has been reported actually to make the cancer cells undergo apoptosis, such as MCF-7 breast cancer cell lines by the down-regulation of Bcl-2 structure [138]. Lastly, FGFs have been resolutely linked with angiogenesis, discussed in the upcoming section.

\section{FGFs and FGFRs: Roles in angiogenesis}

Angiogenesis is the formation of new blood vessels into an organized vasculature system that operates to transport nutrients and supplements to the target cells and tissues that reside within a particular environment, either in the close surroundings or at other distant locations [139]. Many pathological anomalies, as well as developmental mechanisms, have been characterized by angiogenesis that is carried out by several pro-angiogenic factors [140]. Various stimulatory and inhibitory factors maintain an equilibrium which, when disturbed, can result in the generation of several disorganized vessels and therefore, owns the ability to agitate the non-malignant cancer setup and convert it into a malignant form of cancer [141]. With the passage of time, the number of tumor cells within a local tumor microenvironment keeps increasing. These tumor cells tend to escape such surrounding due to the hypoxic conditions created by a large number of cells [142]. Angiogenesis is, in fact, responsible for metastasizing various tumors since it facilitates the movement of tumor cells to other locations. Thus aiding in tumor progression and growth [143].

The generalized concept about angiogenesis involves the induction of endothelial cells by various growth factors like FGF [144] and VEGF [145], etc. Stimulation of ECs allows the endothelial cells (EC) to release various MMPs into the extracellular matrix [146]. Numerous studies have been directed to investigate the role of fibroblast growth factors and their receptors in angiogenesis. In fact, these GFs are among the angiogenic factors that were first specified and are capable of triggering a pro-angiogenic environment that is suitable for carrying the process of angiogenesis. FGFs when to interact with FGFRs on the cell surface of EC, they directly promote tumor angiogenesis. FGFR1 and FGFR2 (in some cases) are only expressed by endothelial cells $[147,148]$. In the group of 22 FGF members, the role of FGF-1 (aFGF) and FGF-2 (bFGF) has been extensively demonstrated as angiogenesis promoting growth factors.

Members of the FGF family are involved in the favorable implementation of angiogenesis by actively maintaining the endothelial cell division, migration, ECM degradation processes and interactions between the cell receptors and effector molecules. When FGF-1, -2 and -4 activate FGF receptor 1 and 2, discrete cellular pathways are triggered that facilitate the maintenance of the proliferative environment of endothelial cells $[149,150]$. FGF-8b is also involved in carrying out the same kind of activity [151]. When FGF-2 stimulate a proliferative response in ECs, PKC is upregulated [152]. When down-regulated, PKC, in turn, diminishes the effect of FGF-2 and as a result, the mitogenic activity is lost. FGFs increase the expression of MMPs and uPA from endothelial cells. In the case of uPA, its receptor expression is, indeed, harmonized on the cell surface by FGF-1, -2 and -4 to increase the efficacy of ECM-degrading mechanism FGF-1, -2 and -4 [153]. Gelatinase A (MMP-2) and gelatinase B (MMP-9) have the potency to carry out angiogenic activities [154]. Their release from the endothelial cells is promoted by FGFs $[155,156]$. Angiogenesis requires the migration of ECs to form the new vessels. FGF-1,-2, -10 and $8 \mathrm{~b}$ induce migratory features in endothelial cells. FGF-2 binds to its receptor and activates MAPK pathway thereby supporting the migration of endothelial cells [157-160]. Certain integrins, cell adhesion molecules, and cadherins mediate endothelial cells interaction with surrounding extracellular components. FGF-2 governs the expression of these molecules on the cell surface of endothelial cells, assisting in the cell distribution, cell-cell communication, and maturation $[161,162]$. Finally, endothelial cell organization and maturation to form the vessel lumen is simplified by the effect of FGF-2 and FGF-8b [163]. This action of FGFs requires backing from several other elements like the expression of TIMPs, MMP-2, MMP-9, uPA, several integrin receptors, etc. Under the effect of FGF-2, signals from VEFG receptor 1 are also significant in the development of mature endothelial cells [164].

FGF-BP (FGF binding protein) is present in various tissues where FGF-2 or other members of FGF family are expressed. This protein competes with heparin sulfate molecules and interacts with FGF2 that is trapped in the extracellular matrix and facilitates its release [165]. When bound to FGF-2, FGF-BP reduces the availability of bFGF to heparin sulfate molecules, stimulating the growth of prostate and adrenal cancer cells in an FGF-2 dependent manner [166,167]. Reduction in the levels of FGF-BP has been correlated with the inhibition of angiogenic activity within the xenograft models of squamous cell cancer, colon cancer as well as prostate cancer $[168,169]$.

In certain inflammatory conditions, angiogenesis could be induced in response to an injury that may be caused by any external stress. Cells found in inflammatory conditions include mast cells, cytotoxic and helper T cells as well as phagocytic cells [170]. Inflammation provokes the release of bFGF from these cells [171]. Moreover, other traumatic conditions may result in the expression of FGF-2 from endothelial cells [172]. Other factors that are responsible for the expedition of FGF-2 release from endothelial cells may include cytokines like IFNa also with IL-2, nitric oxide-NO, and IL- $1 \beta$. NO, produced by the effect of various inflammatory molecules and cytokines, is concerned with the up-regulation of FGF-2 that ultimately leads to the progression of angiogenic activities $[173,174]$. In addition to the data- mentioned above, excessive inflammation may also result in cell damage and hypoxic conditions. Hypoxia stimulates the synthesis of heparin sulfate proteoglycans, thus increasing the impartiality of endothelial cells to FGF-2 [175]. On the other hand, damaged endothelial cells express increased levels of FGF-2, facilitating the synthesis of new vesselsangiogenesis [176,177].

A crosstalk mechanism exists within the tumor microenvironment where various factors coordinate with each other to make sure the survival of tumor cells. As the tumor progresses, the expression profile of tumors also evolves where particular pro- or anti-angiogenic factors may be expressed at one point but might be absent at another $[178,179]$. VEGF is known to regulate and manage the angiogenic process. Upon integration, FGF-2 and VEGF bring about complex mechanisms that are essential for carrying out angiogenic activities [180]. However, the effect of these two GFs is evident at different stages of the process. Almost every step of angiogenesis expresses FGF whereas VEGF is usually observed at the initial phases of tumor development [181,182]. FGF-2 signaling triggers VEGF expression in endothelial cells. A decrease in the expression of VEGF reduces the levels of FGF-2 consequently. Blocking FGFR1 and FGFR2 reduces the levels of VEGF and neovascularization [183]. A study reported an increase in the levels of VEGF and VEGFR1/2 along with the levels of an angiogenic factor Hif- $1 \alpha$, observed in epithelial cells of the prostate tumor, upon induction of FGFR1 [184,185]. FGFR1 functions to promote the paracrine signaling of VEGF on endothelial cells to execute angiogenesis. VEGF and VEGFR signaling pathway may be induced by FGFs, resulting in the indirect stimulation of angiogenesis. FGF-2 
acts to enhance the expression of NRP-1, which serves as a co-factor in VEGF-VEGFR interactions. The expression of NRP-1, when observed in VSMCs, in turn, facilitates the cell migratory properties induced by VEGF [186], thus endorsing the angiogenic process. On the other hand, FGF-2 reinforces the secretion of HIF-1 $\alpha$ that consequently releases VEGF [187]. A reciprocal interaction exists among the VSMCs bearing FGFR1 and endothelial cells that retain PDGFR $\alpha$ and $\beta$. This peculiar communication is carried out by FGF-2, where it operates to make endothelial cells more responsive to PDGF-BB that in turn responses to VSMCs and promotes their reactivity towards FGF-2 by increasing FGFR1 expression. Angiogenesis carried out under the effect of FGF-2 is not entirely dependent on VEGF signaling. According to one report, even in the presence of high levels of VEGF, FGF-2 overexpression can induce angiogenesis [188]. Apart from mediating the VEGF signaling, the FGFR1 is involved in reducing the levels of Angiopoietin 1 while augmenting the expression profile of Angiopoietin 2 [189]. These are angiogenic factors that interact with their respective receptors (RTKs) on endothelial cells. Ang-1 is responsible for maintaining balanced and stabilized embryonic blood vasculature system [190]. Paradoxically, Ang-2 is involved in the disruption of new blood vessels [191]. The presence of Ang-2 and VEGF at the point of angiogenesis suggests the undermining effect of Ang-2 on endothelial cells makes these cells more responsive to VEGF-regulated angiogenesis.

Participation of fibroblast growth factors in commencing and implementing various angiogenic activities is quite evident. Numerous research studies conducted in the recent years have proved the role of FGFs in promoting tumor angiogenesis. However, most of the research administered was based either on animal models or in vitro studies. The link of tumor progression and tumor angiogenesis with FGFs in human cancer requires further affirmatory data. Respective therapeutic techniques have been investigated in various clinical trials to limit the operation of FGFs in the tumoral environment.

\section{Therapeutic inhibition of FGFs-FGFRs}

The association between cancer metastases and angiogenesis is genuinely acceptable. Efforts are being made to develop such kind of drugs that could ultimately limit the effect of FGFs on tumor angiogenesis and the crosstalk mechanism they undergo with various molecules within the tumor microenvironment [192]. FGF-FGFR signaling, apart from directly participating in angiogenesis and tumor growth, is linked with resistance to various VEGF inhibitory therapies, confirming the actuality of cross talk system between FGF and VEGF [193]. Upregulation of interactions among FGF and FGFR may result in resistance to an anti-VEGF therapy [194]. In certain malignancies, FGFs have been reported to hinder the inhibitory action of therapies targeted against VEGF-mediated signaling activities. When studied in transgenic mice models of pancreatic tumor, Rip1-Tag2, blocking of VEGFR elevated the levels of FGF-2. Upon treatment of the same tumor with VEGFR inhibitor alone and later on with an FGF-trap, the result recorded was a decrease in vessel density and tumor progression [195].

Various types of therapeutic drugs have been manufactured and tested for their inhibitory actions against FGFs and VEGF since these two GFs show a highly integrated response mechanism that leads to tumor angiogenesis [196]. Inhibitors developed against VEGF or FGF usually aims the growth factor itself, its receptor or any downstream signaling molecule angiogenic activities [197-199].

Bevacizumab, rhumAb VEGF, is a recombinant monoclonal antibody that binds to VEGF-A growth factor and hinders its interaction with its receptor thus down-regulating angiogenesis, investigated in various studies. However, FGFs' show resistance to its mode of action [200,201]. A treatment study of bevacizumab along with 5-fluorouracil (5-FU), leucovorin, and irinotecan (FOLFIRI) was carried out on the patients of colon cancer to demonstrate the role of FGF-2 against bevacizumab. At various levels of disease progression, FGF-2 levels were assessed. The results displayed an increase in the levels of FGF2 just before cancer progression [202,203]. Another study concerned with renal cancer neoadjuvant therapy included bevacizumab along with other radiations. Here too, FGF-2 showed no response to this treatment, suggesting resistance to bevacizumab [204,205]. An antibody directed against VEGF receptor $2 \mathrm{KDR} / \mathrm{Flk}-1$ obstructs the binding of VEGF with VEGFR2, thus attenuating the signaling pathways directed by VEGF-VEGFR2 interaction [206]. SU6668 is an inhibitor that aims to interrupt the kinase activity of FGFR, VEGF, and PDGFR. Interferon is correlated with inhibition of angiogenesis [207]. Interferon a reduces angiogenic activity that is being maintained by increased levels of FGF-2. It also decreases the expression of FGF-2 from tumor cells. Another inhibitor of FGF-2 induced angiogenesis is thalidomide, which is an immunomodulatory drug [208]. Platelet factor 4 is a CXC chemokine that possesses anti-angiogenic properties. It interacts with FGF-2 and heparin sulfate simultaneously to form a ternary complex and inhibits angiogenesis by binding with FGF-2/HS at the cell surface. It also obstructs the dimerization of bFGF $[209,210]$.

In the past years, advancements in pharmaceutical therapies against FGFs have been made to limit their effects on the cancerous environment. Though, tumor angiogenesis is mainly regulated by VEGF and passively by FGF. However, fibroblast growth factors resist the effects of anti-VEGF therapies, as mentioned earlier. Recently developed techniques against growth factors target FGF receptors to limit angiogenesis. Individual tyrosine kinase inhibitors are being developed, known as "small molecule TKIs" that may act against FGFs either specifically or as a part of the larger target group depending on their mode of action [211]. The primary strategy applied here is to block the ATP binding site of the FGFR receptor. The intracellular tyrosine kinase domain of FGFR contains the ATP site. The "non-specific" TKIs class usually, targets VEGFRs as well as FGFRs since these two have almost identical kinase domain structure. However, nonspecific TKIs have a higher potency to select VEGFR as compared to FGFR [212,213].

Dovitinib (TK1258) is a tyrosine kinase inhibitor that works against several factors like VEGFR1, 2, 3; FGFR1; PDGFR- $\beta$; CSf1 , etc. This compound possesses antitumor and anti-angiogenic properties when it targets receptors like FGFR, PDGFR or VEGFR, FGFR, and PDGFR, respectively. Dovitinib has been investigated in gastrointestinal stromal tumors, endometrial, breast, hepatocellular carcinomas, etc. [214-219]. Side effects recorded in different studies mainly included diarrhea, hypertension, abdominal pain, nausea, dehydration, etc. [220]. E3810 (may or may not be labeled as lucitanib) acts as a dual inhibitor of FGFR1/2 and VEGFR1/2/3 that can be administered orally and is currently in phase II clinical trials. Side effects reported were hypertension, hyperthyroidism, etc. [221-223]. Nintedanib (BIBF1120) is another non-specific TKI that targets VEGFR, FGFR as well as PDGFR. Phase II clinical trials of nintedanib are under way for endometrial cancer, hepatocellular carcinoma, glioblastoma multiform and prostate cancer, etc. This inhibitor mainly causes gastrointestinal side effects [224]. Used as a leading therapy for chronic myelogenous leukemia, Ponatinib (AP24534) is a BCR-ABL tyrosine kinase inhibitor. It also shows anti-angiogenic properties against FGFR1, VEGFR2, PDGFRa, etc. [225,226]. Apart from the above mentioned prominent non-selective TKIs other compounds, 
like brivanib (BMS582664) a dual FGFR/VEGFR inhibitor, ENMD2076, lenvatinib (E7080), orantinib (TSU-68), etc., though have shown anti-FGFR properties. However, their effects against VEGFR or other kinases are more relevant [227-230].

"Selective" TKIs are the other class of inhibitors that specifically target FGFRs. BGJ398 is a selective TKI that targets FGFRs1-3. This compound, either exclusively or in combination with other compounds, is being investigated in various phase II clinical trials of certain tumors [231,232]. The other two selective TKIs are pan (Greek meaning all) inhibitors i.e. they block all FGFRs indiscriminately. These inhibitors are AZD4547 and LY287445 [233,234]. The former is being tested in phase I and II clinical trials whereas the latter has been tested in breast cancer patients during a phase I clinical trial. TAS120, Debio1347, JNJ42756493, and ARQ087 are other specific tyrosine kinase inhibitors that have been developed to hinder the activity of FGFRs [235]. Besides tyrosine kinase inhibitors, other forms of therapies have evolved in the recent years to hinder the activity of FGFRs. These types include monoclonal antibodies directed towards FGFRs [236,237] and FGFligand traps. The novel strategy for blocking FGF/FGFR interaction is the ligand trap. It has the potency to hinder the binding of FGF ligand with its respective receptor. MGFR1877S is a monoclonal antibody that targets FGFR3. FP-1039 is an FGF ligand trap that has been developed by combining the regions of human $\operatorname{IgG}$ and extracellular domain region of FGFR1-IIIc isoform [238].

The developmental steps of FGF/FGFR inhibitors have come across various challenges. When it comes to limiting angiogenic process within a cancerous setting, FGFs or FGFRs alone are not solely responsible for carrying out this particular process. FGF/FGFR targeted remedies need to be combined with other therapies to attain the desired result. Further evaluation of tumor microenvironment and various factors that reside within is required. The timing for the application of a certain therapy is another hurdle. The tumor environment is a dynamic environment that keeps on modifying its expression profile. Hence, any tumor would have unique FGF/FGFR expression levels at certain points, and these levels may decrease or increase as the tumor advances. On the other hand, in such a complex environment administration of a certain therapy usually, faces resistance from some other factor. Identification of such factors makes the developmental process even complicated and time-consuming. Furthermore, selection of patients for conducting a clinical trial, cost effectiveness of therapy, possible adverse outcomes, recurrence time, etc. are some other factors that need to be figured out before launching a treatment against the FGF/FGFR activity.

\section{Drug resistance}

FGFs' expression shows resistance to anti-cancer therapies in certain tumors. In the excess of ligands i.e. GFs, the response of cancer cells to tyrosine kinase inhibitors is impaired. FGF is expressed by stromal cells and resists the anti-cancer effects of imatinib in gastrointestinal stromal cancer. FGFs decrease the anti-cancer effects of imatinib in a mice model of cervical carcinogenesis. FGF-2, when administered on a cell line of human bladder cancer, shows resistance to cisplatin therapy [239]. According to one study, FGF-1 and FGF-2 also resist the response of paclitaxel, doxorubicin, and 5-fluorouracil in metastatic tumors [240]. FGFs and FGFRs resist individual therapies that target cancer cells. In a breast cancer study, FGFR1 overexpression has been correlated with the induction of resistance to 4-hydroxytamoxifen. Certain novel inhibitory techniques have been developed that lower the expression of EGFR along with that of FGFR3 and FGFR2 in the cell lines of non-small cell lung cancer-NSCLC [241]. In a particular type of melanoma, the activation of MAPK pathway by FGFR3 results in the resistance to vemurafenib, an anti-cancer drug [242]. A crosstalk mechanism that exists between FGFR3 and KIT gene induces drug resistance in gastrointestinal stromal cancer [243]. FGFR3 hinders the effects of dexamethasone in multiple myeloma cells [244]. FGFR4 has been linked with drug resistance in colorectal cancer [245]. Selective mutations in FGFR2 can lead to resistance to dovitinib.

An enormous amount of data is available to validate the role of FGF and FGFR in drug resistance. Development of FGF/FGFR combined resistant drugs and exclusively designed clinical trials that implement a combined treatment of specific anti-cancer drugs would help achieve the standardized outcome in the future.

\section{Summary}

Several biological and developmental processes that take place during the lifespan are brought about by Fibroblast growth factors. These growth factors act as ligands and upon binding to their receptorsFGFRs and cooperating with co-factors, i.e., heparin sulfate molecules/ HSPG, trigger a signal transduction cascade that ultimately lead to cell proliferation, cell survival, angiogenesis and other mechanism carried out by this class of GFs. FGFs may act in an endocrine, paracrine or an intracrine manner depending upon their domain structure and secretion.

FGF/FGFRs play a distinct role in facilitating tumor progression and angiogenesis. With the assistance of other elements, particularly VEGF in the case of angiogenesis, FGFs can implement the angiogenic process. Since their discovery in 1970's and revelation of their structure and mode of action in cancer, attempts have been made to restrict their activity. Clinical trials have evaluated several pharmaceutical remedies. Advanced schematic analysis of tumor microenvironment, for isolating determinants that coordinate with the surrounding components to form an alliance and operate as a compact unit to favorably actuate the mechanism of angiogenesis and tumor survival is required. Detailed studies on cancer types specified by FGFs and FGFRs would provide a lead in the future for the better development of medicinal therapeutics.

\section{References}

1. Yun YR, Won JE, Jeon E, Lee S, Kang W, et al. (2010) Fibroblast growth factors: biology, function, and application for tissue regeneration. J Tissue Eng 2010: 218142

2. Ribatti $D(2014)$ The discovery of angiogenic growth factors: the contribution of Italian scientists. Vasc Cell 6: 8

3. Baird A, Esch F, Mormede P, Ueno N, Ling N, et al. (2013) Molecular characterization of fibroblast growth factor: distribution and biological activities in various tissues. Recent progress in hormone research 42: 143-205.

4. Itoh N, Ornitz DM (2011) Fibroblast growth factors: from molecular evolution to roles in development, metabolism and disease. J Biochem 149: 121-130.

5. Olsen SK, Garbi M, Zampieri N, Eliseenkova AV, Ornitz DM, et al. (2003) Fibroblast growth factor (FGF) homologous factors share structural but not functional homology with FGFs. J Biol Chem 278: 34226-34236.

6. Reuss B, Dono R, Unsicker K (2003) Functions of fibroblast growth factor (FGF)2 and FGF-5 in astroglial differentiation and blood-brain barrier permeability: evidence from mouse mutants. J Neurosci 23: 6404-6412.

7. Safran M, Dalah I, Alexander J, Rosen N, Iny Stein T, et al. (2010) GeneCards Version 3: the human gene integrator. Database (Oxford) 2010: baq020.

8. Sun X, Mariani FV, Martin GR (2002) Functions of FGF signalling from the apical ectodermal ridge in limb development. Nature 418: 501-508.

9. UniProt Consortium (2008) The universal protein resource (UniProt). Nucleic Acids Res 36: D190-195

10. Brooks AN, Kilgour E, Smith PD (2012) Molecular pathways: fibroblast growth factor signaling: a new therapeutic opportunity in cancer. Clinical cancer research 18: 1855-1862. 
Citation: Khalid A, Javaid MA (2016) Fibroblast Growth Factors and their Emerging Cancer-Related Aspects. J Cancer Sci Ther 8: 190-205. doi:10.4172/1948-5956.1000413

11. Ornitz DM, Itoh N (2001) Fibroblast growth factors. Genome Biol 2: 1-12.

12. Bergers G, Benjamin LE (2003) Tumorigenesis and the angiogenic switch. Nat Rev Cancer 3: 401-410.

13. Cao R, Eriksson A, Kubo H, Alitalo K, Cao Y, et al. (2004) Comparative evaluation of FGF-2-, VEGF-A-, and VEGF-C-induced angiogenesis, lymphangiogenesis, vascular fenestrations, and permeability. Circulation research 94: 664-670.

14. Kumar-Singh S, Weyler J, Martin MJ, Vermeulen PB, Van Marck E (1999) Angiogenic cytokines in mesothelioma: a study of VEGF, FGF-1 and -, and TGF beta expression. J Pathol 189: 72-78.

15. Fu L, John LM, Adams SH, Yu XX, Tomlinson E, et al. (2004) Fibroblast growth factor 19 increases metabolic rate and reverses dietary and leptin-deficient diabetes. Endocrinology 145: 2594-2603.

16. Kharitonenkov A, Shiyanova TL, Koester A, Ford AM, Micanovic R, et al (2005a) FGF-21 as a novel metabolic regulator. J Clin Invest 115: 1627-1635.

17. Kovesdy CP, Quarles LD (2013) Fibroblast growth factor-23: what we know, what we don't know, and what we need to know. Nephrol Dial Transplant 28: 2228-2236.

18. Wunsch E, Milkiewicz M, Wasik U, Trottier J, Kempinska-Podhorodecka A, et al. (2015) Expression of hepatic Fibroblast Growth Factor 19 is enhanced in Primary Biliary Cirrhosis and correlates with severity of the disease. Sci Rep 5: 13462

19. Bagci O, Kurtgöz S (2015) Amplification of Cellular Oncogenes in Solid Tumors. N Am J Med Sci 7: 341-346.

20. Goldfarb M (2012) Cellular Oncogenes Conferring Growth Factor Independence on NIH 3T3 Cells. In: Bellve AR (Eds). Molecular Mechanisms In Cellular Growth and Differentiation. Academic Press, US.

21. Williams SV, Hurst CD, Knowles MA (2013) Oncogenic FGFR3 gene fusions in bladder cancer. Hum Mol Genet 22: 795-803.

22. Itoh $\mathrm{N}$ (2007) The Fgf families in humans, mice, and zebrafish: their evolutional processes and roles in development, metabolism, and disease. Biol Pharm Bull 30: $1819-1825$.

23. Itoh N, Ornitz DM (2004) Evolution of the Fgf and Fgfr gene families. Trends Genet 20: 563-569.

24. Eswarakumar VP, Lax I, Schlessinger J (2005) Cellular signaling by fibroblas growth factor receptors. Cytokine Growth Factor Rev 16: 139-149.

25. Goetz R, Dover K, Laezza F, Shtraizent N, Huang X, et al. (2009) Crystal structure of a fibroblast growth factor homologous factor (FHF) defines a conserved surface on FHFs for binding and modulation of voltage-gated sodium channels. J biolo chem 284(26): 17883-17896.

26. Arnaud E, Touriol C, Boutonnet C, Gensac MC, Vagner S, et al. (1999) A new $34-$ kilodalton isoform of human fibroblast growth factor 2 is cap dependently synthesized by using a non-AUG start codon and behaves as a survival factor. Molecular and cellular biology 19: 505-514.

27. Pickering BM, Willis AE (2005) The implications of structured 5' untranslated regions on translation and disease. Semin Cell Dev Biol 16: 39-47.

28. Ramsebner R, Ludwig M, Parzefall T, Lucas T, Baumgartner WD, et al. (2010) A FGF3 mutation associated with differential inner ear malformation, microtia, and microdontia. Laryngoscope 120: 359-364.

29. Ornitz DM (2000) FGFs, heparan sulfate and FGFRs: complex interactions essential for development. Bioessays 22: 108-112.

30. Plotnikov AN, Hubbard SR, Schlessinger J, Mohammadi M (2000) Crysta structures of two FGF-FGFR complexes reveal the determinants of ligandreceptor specificity. Cell 101: 413-424

31. Mohammadi M, Olsen SK, Ibrahimi OA (2005) Structural basis for fibroblast growth factor receptor activation. Cytokine Growth Factor Rev 16: 107-137.

32. Faham S, Linhardt RJ, Rees DC (1998) Diversity does make a difference: fibroblast growth factor-heparin interactions. Curr Opin Struct Biol 8: 578-586.

33. Kolli V, Paul S, Sarkar N (2015) An Overview on Fibroblast Growth Factors: Structural, Functional and Therapeutic Implications. Current Proteomics 12 144-151.

34. Friesel R, Maciag T (1999) Fibroblast growth factor prototype release and fibroblast growth factor receptor signaling. Thromb Haemost 82: 748-754.
35. Antoine M, Reimers K, Dickson C, Kiefer P (1997) Fibroblast growth factor, a protein with dual subcellular localization, is targeted to the nucleus and nucleolus by the concerted action of two nuclear localization signals and a nucleolar retention signal. J Biol Chem 272: 29475-29481.

36. Ron D, Bottaro DP, Finch PW, Morris D, Rubin JS, et al. (1993) Expression of biologically active recombinant keratinocyte growth factor. Structure/function analysis of amino-terminal truncation mutants. J biol chem 268: 2984-2988.

37. Nyeng P, Norgaard GA, Kobberup S, Jensen J (2007) FGF10 signaling controls stomach morphogenesis. Dev Biol 303: 295-310.

38. Goldfarb M (2005) Fibroblast growth factor homologous factors: evolution, structure, and function. Cytokine Growth Factor Rev 16: 215-220.

39. Huret JL, Ahmad M, Arsaban M, Bernheim A, Cigna J, et al. (2013) Atlas of genetics and cytogenetics in oncology and haematology in 2013. Nucleic acids research 41: D920-D924.

40. Presta M, Dell'Era P, Mitola S, Moroni E, Ronca R, et al. (2005) Fibroblast growth factor/fibroblast growth factor receptor system in angiogenesis. Cytokine Growth Factor Rev 16: 159-178.

41. Kelleher FC, O'sullivan H, Smyth E, Mcdermott R, Viterbo A (2013) Fibroblas growth factor receptors, developmental corruption and malignant disease. Carcinogenesis 34: 2198-2205

42. Wang F, Kan M, Yan G, Xu J, McKeehan WL (1995) Alternately spliced NH2 terminal immunoglobulin-like Loop I in the ectodomain of the fibroblast growth factor (FGF) receptor 1 lowers affinity for both heparin and FGF-1. J Biol Chem 270: 10231-10235

43. Beenken A, Mohammadi M (2009) The FGF family: biology, pathophysiology and therapy. Nat Rev Drug Discov 8: 235-253.

44. Steinberg Z, Myers C, Heim VM, Lathrop CA, Rebustini IT, et al. (2005) FGFR2b signaling regulates ex vivo submandibular gland epithelial cell proliferation and branching morphogenesis. Development 132: 1223-1234.

45. Hughes-Fulford M, Li CF (2011) The role of FGF-2 and BMP-2 in regulation of gene induction, cell proliferation and mineralization. J Orthop Surg Res 6: 8 .

46. Dignass AU, Tsunekawa S, Podolsky DK (1994) Fibroblast growth factors modulate intestinal epithelial cell growth and migration. Gastroenterology 106 1254-1262.

47. Maric D, Fiorio Pla A, Chang YH, Barker JL (2007) Self-renewing and differentiating properties of cortical neural stem cells are selectively regulated by basic fibroblast growth factor (FGF) signaling via specific FGF receptors. $J$ Neurosci 27: 1836-1852.

48. Ye F, Duvillie B, Scharfmann R (2005) Fibroblast growth factors 7 and 10 are expressed in the human embryonic pancreatic mesenchyme and promote the proliferation of embryonic pancreatic epithelial cells. Diabetologia 48: 277-281.

49. Agata H, Asahina I, Yamazaki Y, Uchida M, Shinohara Y, et al. (2007) Effective bone engineering with periosteum-derived cells. J Dent Res 86: 79-83.

50. Liu Z, Lavine KJ, Hung IH, Ornitz DM (2007) FGF18 is required for early chondrocyte proliferation, hypertrophy and vascular invasion of the growth plate. Dev Biol 302: 80-91.

51. Memarzadeh S, Xin L, Mulholland DJ, Mansukhani A, Wu H, et al. (2007) Enhanced paracrine FGF10 expression promotes formation of multifocal prostate adenocarcinoma and an increase in epithelial androgen receptor. Cancer cell 12: 572-585

52. Ciruna B, Rossant J (2001) FGF signaling regulates mesoderm cell fate specification and morphogenetic movement at the primitive streak Developmental cell 1: $37-49$.

53. Hossain WA, Morest D (2000) Fibroblast growth factors (FGF-, FGF-2) promote migration and neurite growth of mouse cochlear ganglion cells in vitro: Immunohistochemistry and antibody perturbation. J Neurosci Res 62: 40-55.

54. Pintucci G, Moscatelli D, Saponara F, Biernacki PR, Baumann FG, et al. (2002) Lack of ERK activation and cell migration in FGF-2-deficient endothelial cells. FASEB J 16: 598-600.

55. Niu J, Chang Z, Peng B, Xia Q, Lu W, et al. (200) Keratinocyte growth factor/ fibroblast growth factor-7-regulated cell migration and invasion through activation of NF-kappaB transcription factors. J Biol Chem 282: 6001-6011.

56. Werner S, Krieg T, Smola H (2007) Keratinocyte-fibroblast interactions in wound healing. J Invest Dermatol 127: 998-1008. 
Citation: Khalid A, Javaid MA (2016) Fibroblast Growth Factors and their Emerging Cancer-Related Aspects. J Cancer Sci Ther 8: 190-205. doi:10.4172/1948-5956.1000413

57. Sato A, Scholl AM, Kuhn EN, Stadt HA, Decker JR, et al. (2011) FGF8 signaling is chemotactic for cardiac neural crest cells. Dev Biol 354: 18-30.

58. Xu X, Browning VL, Odorico JS (2011) Activin, BMP and FGF pathways cooperate to promote endoderm and pancreatic lineage cell differentiation from human embryonic stem cells. Mech Dev 128: 412-427.

59. Solchaga LA, Penick K, Porter JD, Goldberg VM, Caplan AI, et al. (2005) FGF-2 enhances the mitotic and chondrogenic potentials of human adult bone marrow-derived mesenchymal stem cells. J Cell Physiol 203: 398-409.

60. Sahni A, Khorana AA, Baggs RB, Peng H, Francis CW (2006) FGF-2 binding to fibrin(ogen) is required for augmented angiogenesis. Blood 107: 126-131.

61. Carmeliet $P$, Jain RK (2011) Molecular mechanisms and clinical applications of angiogenesis. Nature 473: 298-307.

62. Forough R, Weylie B, Patel C, Ambrus S, Singh US, et al. (2005) Role of AKT/ $\mathrm{PKB}$ signaling in fibroblast growth factor-1 (FGF-1)-induced angiogenesis in the chicken chorioallantoic membrane (CAM). J Cell Biochem 94: 109-116.

63. Mori S, Tran V, Nishikawa K, Kaneda T, Hamada Y, et al. (2013) A dominantnegative FGF1 mutant (the R50E mutant) suppresses tumorigenesis and angiogenesis. PLoS One 8: e57927.

64. Clark RAF, Henson PM (2013) The molecular and cellular biology of wound repair. Springer Science \& Business Media, Newyork.

65. Presta M, Camozzi M, Salvatori G, Rusnati M (2007) Role of the soluble pattern recognition receptor PTX3 in vascular biology. J Cell Mol Med 11: 723-738.

66. Rusnati M, Presta M (2007) Fibroblast growth factors/fibroblast growth factor receptors as targets for the development of anti-angiogenesis strategies. Curr Pharm Des 13: 2025-2044.

67. Gurtner GC, Werner S, Barrandon Y, Longaker MT (2008) Wound repair and regeneration. Nature 453: 314-321.

68. Naggi A, Casu B, Perez M, Torri G, Cassinelli G, et al. (2005) Modulation of the heparanase-inhibiting activity of heparin through selective desulfation, graded $\mathrm{N}$-acetylation, and glycol splitting. J Biol Chem 280: 12103-12113.

69. Hodde JP, Ernst DM, Hiles MC (2005) An investigation of the long-term bioactivity of endogenous growth factor in OASIS Wound Matrix. J Wound Care 14: $23-25$.

70. Rossini M, Cheunsuchon B, Donnert E, Ma LJ, Thomas JW, et al. (2005) Immunolocalization of fibroblast growth factor-1 (FGF-1), its receptor (FGFR1 ), and fibroblast-specific protein-1 (FSP-1) in inflammatory renal disease. Kidney international. 68: 2621-2628.

71. Soldi R, Mandinova A, Venkataraman K, Hla T, Vadas M, et al. (2007) Sphingosine kinase 1 is a critical component of the copper-dependent FGF1 export pathway. Exp Cell Res 313: 3308-3318.

72. Yin T, Li L (2006) The stem cell niches in bone. J Clin Invest 116: 1195-1201.

73. Stappenbeck TS, Miyoshi H (2009) The role of stromal stem cells in tissue regeneration and wound repair. Science 324: 1666-1669.

74. Kalghatgi S, Friedman G, Fridman A, Clyne AM (2010) Endothelial cell proliferation is enhanced by low dose non-thermal plasma through fibroblast growth factor-2 release. Annals of Biomedical Engineering 38: 748-757.

75. Poettler M, Unseld M, Mihaly-Bison J, Uhrin P, Koban F, et al. (2012) The urokinase receptor (CD87) represents a central mediator of growth factorinduced endothelial cell migration. Thrombosis and haemostasis 108: 357-366.

76. Lamalice L, Le Boeuf F, Huot J (2007) Endothelial cell migration during angiogenesis. Circ Res 100: 782-794.

77. Barrientos S, Stojadinovic O, Golinko MS, Brem H, Tomic-Canic M (2008) Growth factors and cytokines in wound healing. Wound Repair Regen 16: 585-601.

78. Satoh A, Bryant SV, Gardiner DM (2008) Regulation of dermal fibroblast dedifferentiation and redifferentiation during wound healing and limb regeneration in the Axolotl. Development, growth \& differentiation 50: 743-754.

79. Bénazet JD, Zeller R (2009) Vertebrate limb development: moving from classical morphogen gradients to an integrated 4-dimensional patterning system. Cold Spring Harb Perspect Biol 1: a001339.

80. Mariani FV, Ahn CP, Martin GR (2008) Genetic evidence that FGFs have an instructive role in limb proximal-distal patterning. Nature 453: 401-405.
81. Katoh M, Nakagama H (2014) FGF receptors: cancer biology and therapeutics Med Res Rev 34: 280-300.

82. Turner N, Grose R (2010) Fibroblast growth factor signalling: from development to cancer. Nat Rev Cancer 10: 116-129.

83. Allerstorfer S, Sonvilla G, Fischer H, Spiegl-Kreinecker S, Gauglhofer C, et al. (2008) FGF5 as an oncogenic factor in human glioblastoma multiforme: autocrine and paracrine activities. Oncogene 27: 4180-4190.

84. Baritaki S, Chatzinikola AM, Vakis AF, Soulitzis N, Karabetsos DA, et al. (2009) YY1 Over-expression in human brain gliomas and meningiomas correlates with TGF-beta, IGF-1 and FGF-2 mRNA levels. Cancer Invest 27: 184-192.

85. Su G, Meyer K, Nandini CD, Qiao D, Salamat S, et al. (2006) Glypican-1 is frequently overexpressed in human gliomas and enhances FGF-2 signaling in glioma cells. Am J Pathol 168: 2014-2026.

86. Chen Q, Jin M, Yang F, Zhu J, Xiao Q, et al. (2013) Matrix metalloproteinases: inflammatory regulators of cell behaviors in vascular formation and remodeling Mediators Inflamm 2013: 928315.

87. Abuharbeid S, Czubayko F, Aigner A (2006) The fibroblast growth factorbinding protein FGF-BP. Int J Biochem Cell Biol 38: 1463-1468.

88. Korc M, Friesel RE (2009) The role of fibroblast growth factors in tumor growth Curr Cancer Drug Targets 9: 639-651.

89. Yang F, Zhang Y, Ressler SJ, Ittmann MM, Ayala GE, et al. (2013) FGFR1 is essential for prostate cancer progression and metastasis. Cancer Res 73 3716-3724.

90. Zhu ML, Kyprianou N (2008) Androgen receptor and growth factor signaling cross-talk in prostate cancer cells. Endocr Relat Cancer 15: 841-849.

91. Acevedo VD, Ittmann M, Spencer DM (2009) Paths of FGFR-driven tumorigenesis. Cell Cycle 8: 580-588.

92. Feng S, Wang F, Matsubara A, Kan M, Mckeehan WL (1997) Fibroblast growth factor receptor 2 limits and receptor 1 accelerates tumorigenicity of prostate epithelial cells. Cancer Res 57: 5369-5378.

93. Hunter DJ, Kraft P, Jacobs KB, Cox DG, Yeager M, et al. (2007) A genomewide association study identifies alleles in FGFR2 associated with risk of sporadic postmenopausal breast cancer. Nature genetics 39: 870-874.

94. Grose R, Dickson C (2005) Fibroblast growth factor signaling in tumorigenesis Cytokine Growth Factor Rev 16: 179-186.

95. Zhang J, Li Y, Liu Q, Lu W, Bu G (2010) Wnt signaling activation and mammary gland hyperplasia in MMTV-LRP6 transgenic mice: implication for breast cancer tumorigenesis. Oncogene 29: 539-549.

96. Pond AC, Herschkowitz JI, Schwertfeger KL, Welm B, Zhang Y, et al. (2010) Fibroblast growth factor receptor signaling dramatically accelerates tumorigenesis and enhances oncoprotein translation in the mouse mammary tumor virus-Wnt-1 mouse model of breast cancer. Cancer Res 70: 4868-4879.

97. Huang X, Godfrey TE, Gooding WE, McCarty KS, Gollin SM (2006) Comprehensive genome and transcriptome analysis of the $11 \mathrm{q} 13$ amplicon in human oral cancer and synteny to the 7F5 amplicon in murine oral carcinoma. Genes, Chromosomes and Cancer 45: 1058-1069.

98. Karlsson E, Waltersson MA, Bostner J, Pérez-Tenorio G, Olsson B, et al (2011) High-resolution genomic analysis of the $11 q 13$ amplicon in breast cancers identifies synergy with $8 \mathrm{p} 12$ amplification, involving the mTOR targets S6K2 and 4EBP1. Genes, Chromosomes and Cancer 50: 775-787.

99. Bane AL, Pinnaduwage D, Colby S, Bull SB, O'Malley FP, et al. (2009) Expression profiling of familial breast cancers demonstrates higher expression of FGFR2 in BRCA2-associated tumors. Breast Cancer Res Treat 117: 183-191.

100. Meijer D, Van Agthoven T, Bosma PT, Nooter K, Dorssers LC (2006) Functional screen for genes responsible for tamoxifen resistance in human breast cancer cells. Mol Cancer Res 4: 379-386.

101. Turner N, Pearson A, Sharpe R, Lambros M, Geyer F, et al. (2010a) FGFR1 amplification drives endocrine therapy resistance and is a therapeutic target in breast cancer. Cancer Res 70: 2085-2094.

102. Reis-Filho JS, Simpson PT, Turner NC, Lambros MB, Jones C, et al (2006) FGFR1 emerges as a potential therapeutic target for lobular breast carcinomas. Clin Cancer Res 12: 6652-6662.

103. Thussbas C, Nahrig J, Streit S, Bange J, Kriner M, et al. (2006) FGFR4 Arg388 
Citation: Khalid A, Javaid MA (2016) Fibroblast Growth Factors and their Emerging Cancer-Related Aspects. J Cancer Sci Ther 8: 190-205. doi:10.4172/1948-5956.1000413

allele is associated with resistance to adjuvant therapy in primary breast cancer. J Clin Oncol 24: 3747-3755.

104. Katoh M (2009) FGFR2 abnormalities underlie a spectrum of bone, skin, and cancer pathologies. J Invest Dermatol 129: 1861-1867.

105. Lamont F, Tomlinson D, Cooper P, Shnyder S, Chester JD, et al. (2011) Small molecule FGF receptor inhibitors block FGFR-dependent urothelial carcinoma growth in vitro and in vivo. Br J Cancer 104: 75-82.

106. Fukai J, Yokote H, Yamanaka R, Arao T, Nishio K, et al. (2008) EphA4 promotes cell proliferation and migration through a novel EphA4-FGFR1 signaling pathway in the human glioma U251 cell line. Mol Cancer Ther 7: 2768-2778.

107. Gotoh N (2008) Regulation of growth factor signaling by FRS2 family docking/ scaffold adaptor proteins. Cancer Sci 99: 1319-1325.

108. Easton JB, Royer AR, Middlemas DS (2006) The protein tyrosine phosphatase, Shp, is required for the complete activation of the RAS/MAPK pathway by brain-derived neurotrophic factor. J Neurochem 97: 834-845.

109. Powers CJ, McLeskey SW, Wellstein A (2000) Fibroblast growth factors, their receptors and signaling. Endocr Relat Cancer 7: 165-197.

110. Mendoza S, David H, Gaylord GM, Miller CW (2005) Allelic loss at 10q26 in osteosarcoma in the region of the BUB3 and FGFR2 genes. Cancer Genet Cytogenet 158: 142-147.

111. Tsimafeyeu I, Demidov L, Stepanova E, Wynn N, Ta H (2011) Overexpression of fibroblast growth factor receptors FGFR1 and FGFR2 in renal cell carcinoma. Scand J Urol Nephrol 45: 190-195.

112. Kunii K, Davis L, Gorenstein J, Hatch H, Yashiro M, et al. (2008) FGFR2amplified gastric cancer cell lines require FGFR2 and Erbb3 signaling for growth and survival. Cancer Res 68: 2340-2348.

113. Meyer KB, Maia AT, O'Reilly M, Teschendorff AE, Chin SF, et al. (2008) Allelespecific up-regulation of FGFR2 increases susceptibility to breast cancer. PLoS Biol 6: e108.

114. Gomez-Roman JJ, Saenz P, Molina M, Cuevas Gonzalez J, Escuredo K, et al. (2005) Fibroblast growth factor receptor 3 is overexpressed in urinary tract carcinomas and modulates the neoplastic cell growth. Clin Cancer Res 11: 459-465.

115. Kalff A, Spencer A (2012) The t 4 ; 14) translocation and FGFR3 overexpression in multiple myeloma: prognostic implications and current clinical strategies. Blood Cancer J 2: e89.

116. Qing J, Du X, Chen Y, Chan P, Li H, et al. (2009) Antibody-based targeting of FGFR3 in bladder carcinoma and $t(4 ; 14)$-positive multiple myeloma in mice. $J$ Clin Invest 119: 1216-1229.

117. Klinck R, Bramard A, Inkel L, Dufresne-Martin G, Gervais-Bird J, et al. (2008) Multiple alternative splicing markers for ovarian cancer. Cancer Res 68: 657-663.

118. Venables JP (2006) Unbalanced alternative splicing and its significance in cancer. Bioessays 28: 378-386.

119. Hernandez S, Lopez-Knowles E, Lloreta J, Kogevinas M, Amoros A, et al. (2006) Prospective study of FGFR3 mutations as a prognostic factor in nonmuscle invasive urothelial bladder carcinomas. J Clin Oncol 24: 3664-3671.

120. Van Oers JM, Wild PJ, Burger M, Denzinger S, Stoehr R, et al. (2007) FGFR3 mutations and a normal CK20 staining pattern define low-grade noninvasive urothelial bladder tumours. Eur Urol 52: 760-768.

121. Singh D, Chan JM, Zoppoli $P$, Niola F, Sullivan R, et al. (2012) Transforming fusions of FGFR and TACC genes in human glioblastoma. Science 337: 1231-1235.

122. Wu YM, Su F, Kalyana-Sundaram S, Khazanov N, Ateeq B, et al. (2013) Identification of targetable FGFR gene fusions in diverse cancers. Cancer Discov 3: 636-647.

123. Carneiro BA, Elvin JA, Kamath SD, Ali SM, Paintal AS, et al. (2015) FGFR3TACC3: A novel gene fusion in cervical cancer. Gynecol Oncol Rep 13: 53-56.

124.Ang C (2015) Role of the fibroblast growth factor receptor axis in cholangiocarcinoma. J Gastroenterol Hepatol 30: 1116-1122.

125. Dutt A, Salvesen HB, Chen TH, Ramos AH, Onofrio RC, et al. (2008) Drugsensitive FGFR2 mutations in endometrial carcinoma. Proc Natl Acad Sci U S A 105: 8713-8717.

126. Kawase R, Ishiwata T, Matsuda Y, Onda M, Kudo M, et al. (2010) Expression of fibroblast growth factor receptor 2 IIIc in human uterine cervical intraepithelial neoplasia and cervical cancer. Int J Oncol 36: 331-340.

127.Liao RG, Jung J, Tchaicha J, Wilkerson MD, Sivachenko A, et al. (2013) Inhibitor-sensitive FGFR2 and FGFR3 mutations in lung squamous cell carcinoma. Cancer Res 73: 5195-5205.

128. Byron SA, Gartside MG, Wellens CL, Goodfellow PJ, Birrer MJ, et al. (2010) FGFR2 mutations are rare across histologic subtypes of ovarian cancer. Gynecol Oncol 117: 125-129.

129. Matsumoto K, Arao T, Hamaguchi T, Shimada Y, Kato K, et al. (2012) FGFR2 gene amplification and clinicopathological features in gastric cancer. $\mathrm{Br} \mathrm{J}$ Cancer 106: 727-732.

130. Tomlinson DC, Knowles MA, Speirs V (2012) Mechanisms of FGFR3 actions in endocrine resistant breast cancer. Int J Cancer 130: 2857-2866.

131. Marek L, Ware KE, Fritzsche A, Hercule P, Helton WR, et al. (2009) Fibroblast growth factor (FGF) and FGF receptor-mediated autocrine signaling in nonsmall-cell lung cancer cells. Mol Pharmacol 75: 196-207.

132. Schildhaus HU, Heukamp LC, Merkelbach-Bruse S, Riesner K, Schmitz K et al. (2012) Definition of a fluorescence in-situ hybridization score identifies high- and low-level FGFR1 amplification types in squamous cell lung cancer. Mod Pathol 25: 1473-1480.

133. Wang J, Yu W, Cai Y, Ren C, Ittmann MM (2008) Altered fibroblast growth factor receptor 4 stability promotes prostate cancer progression. Neoplasia 10: $847-856$.

134. Motomura K, Hagiwara A, Komi-Kuramochi A, Hanyu Y, Honda E, et al. (2008) An FGF1: FGF2 chimeric growth factor exhibits universal FGF receptor specificity, enhanced stability and augmented activity useful for epithelial proliferation and radioprotection. Biochim Biophys Acta 1780: 1432-1440.

135. Fang F, Chang RM, Yu L, Lei X, Xiao S, et al. (2015) MicroRNA-188-5p suppresses tumor cell proliferation and metastasis by directly targeting FGF5 in hepatocellular carcinoma. J Hepatol 63: 874-885.

136. Su G, Blaine SA, Qiao D, Friedl A (2007) Shedding of syndecan-1 by stromal fibroblasts stimulates human breast cancer cell proliferation via FGF2 activation. J Biol Chem 282: 14906-14915.

137. Agas D, Marchetti L, Menghi G, Materazzi S, Materazzi G, et al. (2008) Antiapoptotic $\mathrm{Bcl}-2$ enhancing requires FGF-2/FGF receptor 1 binding in mouse osteoblasts. J Cell Physiol 214: 145-152.

138. Pardo OE, Wellbrock C, Khanzada UK, Aubert M, Arozarena I, et al. (2006) FGF-2 protects small cell lung cancer cells from apoptosis through a complex involving PKCepsilon, B-Raf and S6K2. EMBO J 25: 3078-3088.

139. Von Willebrand M, Köhler K, Alanko T, Laiho M, SAKSELA O (2005) FGF2 blocks TGF-ß1-mediated suppression of $\mathrm{Bcl}-2$ in normal melanocytes. Experimental dermatology 14: 202-208.

140. Nagy JA, Benjamin L, Zeng H, Dvorak AM, Dvorak HF (2008) Vascular permeability, vascular hyperpermeability and angiogenesis. Angiogenesis 11 : 109-119.

141. Carmeliet $P$ (2005) Angiogenesis in life, disease and medicine. Nature 438 932-936.

142. Prager GW, Poettler M (2012) Angiogenesis in cancer. Basic mechanisms and therapeutic advances. Hamostaseologie 32: 105-114.

143. Fong GH (2008) Mechanisms of adaptive angiogenesis to tissue hypoxia Angiogenesis 11: 121-140.

144. Gupta GP, Massagué J (2006) Cancer metastasis: building a framework. Cell 127: 679-695.

145. Cao Y, Cao R, Hedlund EM (2008) R Regulation of tumor angiogenesis and metastasis by FGF and PDGF signaling pathways. J Mol Med (Berl) 86: 785-789.

146. Hicklin DJ, Ellis LM (2005) Role of the vascular endothelial growth factor pathway in tumor growth and angiogenesis. J Clin Oncol 23: 1011-1027.

147. Ardi VC, van Den Steen PE, Opdenakker G, Schweighofer B, Deryugina El, et al. (2009) Neutrophil MMP-9 proenzyme, unencumbered by TIMP-, undergoes efficient activation in vivo and catalytically induces angiogenesis via a basic fibroblast growth factor (FGF-2)/FGFR-2 pathway. J Biol Chem 284: 25854-25866.

148. Antoine M, Wirz W, Tag C, Mavituna M, Emans N, et al. (2005) Expression pattern of fibroblast growth factors (FGFs), their receptors and antagonists in 
Citation: Khalid A, Javaid MA (2016) Fibroblast Growth Factors and their Emerging Cancer-Related Aspects. J Cancer Sci Ther 8: 190-205. doi:10.4172/1948-5956.1000413

primary endothelial cells and vascular smooth muscle cells. Growth Factors 23: 87-95.

149.Pober JS, Sessa WC (2007) Evolving functions of endothelial cells in inflammation. Nat Rev Immunol 7: 803-815.

150. Ferrara N, Kerbel RS (2005) Angiogenesis as a therapeutic target. Nature 438: $967-974$

151.Virag JA, Rolle ML, Reece J, Hardouin S, Feigl EO, et al. (2007) Fibroblast growth factor-2 regulates myocardial infarct repair: effects on cell proliferation, scar contraction, and ventricular function. Am j pathol 171: 1431-1440.

152. Yang X, Qiao D, Meyer K, Friedl A (2009) Signal transducers and activators of transcription mediate fibroblast growth factor-induced vascular endothelial morphogenesis. Cancer research 69: 1668-1677.

153. Srisakuldee W, Nickel BE, Fandrich RR, Jiang Z, Kardami E (2009) Administration of FGF-2 to the heart stimulates connexin-43 phosphorylation at protein kinase $C$ target sites. Cell communication \& adhesion, 13: 13-19.

154. Otrock ZK, Mahfouz RA, Makarem JA, Shamseddine Al (2007) Understanding the biology of angiogenesis: review of the most important molecular mechanisms. Blood Cells Mol Dis 39: 212-220.

155.Zheng H, Takahashi H, Murai Y, Cui Z, Nomoto K, et al. (2006) Expressions of MMP-, MMP-9 and VEGF are closely linked to growth, invasion, metastasis and angiogenesis of gastric carcinoma. Anticancer Res 26: 3579-3583.

156. Khalil AA, Friedl P (2010) Determinants of leader cells in collective cell migration. Integr Biol (Camb) 2: 568-574.

157. Taraboletti G, D'ascenzo S, Borsotti P, Giavazzi R, Pavan A, et al. (2002) Shedding of the matrix metalloproteinases MMP-, MMP-9, and MT1-MMP as membrane vesicle-associated components by endothelial cells. Am J Pathol 160: $673-680$.

158. Giusti I, Rughetti A, D'ascenzo S, Millimaggi D, Pavan A, et al. (2009) Identification of an optimal concentration of platelet gel for promoting angiogenesis in human endothelial cells. Transfusion 49: 771-778.

159. Leali D, Alessi P, Coltrini D, Ronca R, Corsini M, et al. (2011) Long pentraxin-3 inhibits FGF8b-dependent angiogenesis and growth of steroid hormoneregulated tumors. Mol Cancer Ther 10: 1600-1610.

160. Nillesen ST, Geutjes PJ, Wismans R, Schalkwijk J, Daamen WF, et al. (2007) Increased angiogenesis and blood vessel maturation in acellular collagenheparin scaffolds containing both FGF2 and VEGF. Biomaterials 28: 11231131.

161. Nomura S, Yoshitomi H, Takano S, Shida T, Kobayashi S, et al. (2008) FGF10/ FGFR2 signal induces cell migration and invasion in pancreatic cancer. $\mathrm{Br} J$ Cancer 99: 305-313.

162. Mahabeleshwar GH, Feng W, Reddy K, Plow EF, et al. (2007) Mechanisms of integrin-vascular endothelial growth factor receptor cross-activation in angiogenesis. Circ Res 101: 570-580.

163. Underwood PA, Bean PA, Gamble JR (2002) Rate of endothelial expansion is controlled by cell:cell adhesion. Int J Biochem Cell Biol 34: 55-69.

164. Gnanapragasam VJ, Robinson MC, Marsh C, Robson CN, Hamdy FC, et al. (2003) FGF8 isoform b expression in human prostate cancer. $\mathrm{Br} \mathrm{J}$ Cancer 88 : $1432-1438$.

165. Ribatti D1 (2007) The discovery of endothelial progenitor cells. An historical review. Leuk Res 31: 439-444.

166. Tassi E, Wellstein A (2006) The angiogenic switch molecule, secreted FGFbinding protein, an indicator of early stages of pancreatic and colorectal adenocarcinoma. Semin in oncology 33: S50-S56.

167. Czubayko F, Liaudet-Coopman ED, Aigner A, Tuveson AT, Berchem GJ, et al. (1997) A secreted FGF-binding protein can serve as the angiogenic switch in human cancer. Nat Med 3: 1137-1140.

168. Harris VK, Kagan BL, Ray R, Coticchia CM, Liaudet-Coopman ED, et al (2001) Serum induction of the fibroblast growth factor-binding protein (FGF$\mathrm{BP})$ is mediated through ERK and p38 MAP kinase activation and C/EBPregulated transcription. Oncogene 20: 1730-1738.

169. Sahni A, Simpson-Haidaris P, Sahni S, Vaday G, Francis C (2008) Fibrinogen synthesized by cancer cells augments the proliferative effect of fibroblast growth factor-2 (FGF-2). J Thromb Haemost 6: 176-183.
170.Schulze D, Plohmann P, Höbel S, Aigner A (2011) Anti-tumor effects of fibroblast growth factor-binding protein (FGF-BP) knockdown in colon carcinoma. Mol Cancer 10: 144.

171. Mantovani A, Allavena P, Sica A, Balkwill F (2008) Cancer-related inflammation. Nature 454: 436-444.

172. Presta M, Andrés G, Leali D, Dell'era P, Ronca R (2009) Inflammatory cells and chemokines sustain FGF2-induced angiogenesis. European cytokine network 20: 39-50.

173. Calvani M, Rapisarda A, Uranchimeg B, Shoemaker RH, Melillo G (2006) Hypoxic induction of an HIF-1alpha-dependent bFGF autocrine loop drives angiogenesis in human endothelial cells. Blood 107: 2705-2712.

174.Zheng J, Wen Y, Austin JL, Chen DB (2006) Exogenous nitric oxide stimulates cell proliferation via activation of a mitogen-activated protein kinase pathway in ovine fetoplacental artery endothelial cells. Biol Reprod 74: 375-382.

175.Ziche M, Morbidelli L (2009) Molecular regulation of tumour angiogenesis by nitric oxide. Eur Cytokine Netw 20: 164-170.

176. Leali D, Alessi P, Coltrini D, Rusnati M, Zetta L, et al. (2009) Fibroblast growth factor-2 antagonist and antiangiogenic activity of long-pentraxin 3-derived synthetic peptides. Curr Pharm Des 15: 3577-3589.

177. Kalghatgi SU, Fridman G, Fridman A, Friedman G, Clyne AM (2008) Nonthermal dielectric barrier discharge plasma treatment of endothelial cells. $30^{\text {th }}$ Annual International Conference of the IEEE IEEE 2008: 3578-3581.

178. Lee JG, Kay EP (2006) FGF-2-mediated signal transduction during endothelial mesenchymal transformation in corneal endothelial cells. Exp Eye Res 83: 1309-1316.

179. Adachi Y, Takeuchi T, Sonobe H, Ohtsuki Y (2006) An adiponectin receptor T-cadherin, was selectively expressed in intratumoral capillary endothelial cells in hepatocellular carcinoma: possible cross talk between T-cadherin and FGF-2 pathways. Virchows Archiv 448: 311-318.

180. Murakami M, Nguyen LT, Hatanaka K, Schachterle W, Chen PY, et al. (2011) FGF-dependent regulation of VEGF receptor 2 expression in mice. $\mathrm{J}$ Clin Invest 121: 2668-2678.

181. Cao Y (2007) Angiogenesis modulates adipogenesis and obesity. J Clin Invest 117: $2362-2368$

182. Jain RK1 (2005) Normalization of tumor vasculature: an emerging concept in antiangiogenic therapy. Science 307: 58-62.

183. Seghezzi G, Patel S, Ren CJ, Gualandris A, Pintucci G, et al. (1998) Fibroblas growth factor-2 (FGF-2) induces vascular endothelial growth factor (VEGF) expression in the endothelial cells of forming capillaries: an autocrine mechanism contributing to angiogenesis. J Cell Biol 141: 1659-1673.

184. Taeger J, Moser C, Hellerbrand C, Mycielska ME, Glockzin G, et al. (2011) Targeting FGFR/PDGFR/VEGFR impairs tumor growth, angiogenesis, and metastasis by effects on tumor cells, endothelial cells, and pericytes in pancreatic cancer. Mol Cancer Ther 10: 2157-2167.

185. Boddy JL, Fox SB, Han C, Campo L, Turley H, et al. (2005) The androgen receptor is significantly associated with vascular endothelial growth factor and hypoxia sensing via hypoxia-inducible factors HIF-1a, HIF-2a, and the proly hydroxylases in human prostate cancer. Clin Cancer Res 11: 7658-7663.

186. Shi Y, Wang Y, Bingle L, Gong L, Heng W, et al. (2005) In vitro study of HIF-1 activation and VEGF release by bFGF in the T47D breast cancer cell ine under normoxic conditions: involvement of PI-3K/Akt and MEK1/ERK pathways. J Pathol 205: 530-536.

187. Liu W, Parikh AA, Stoeltzing O, Fan F, Mccarty MF, et al. (2005) Upregulation of neuropilin-1 by basic fibroblast growth factor enhances vascular smooth muscle cell migration in response to VEGF. Cytokine 32: 206-212.

188. Shi YH, Bingle L, Gong LH, Wang YX, Corke KP, et al. (2007) Basic FGF augments hypoxia induced HIF-1-alpha expression and VEGF release in T47D breast cancer cells. Pathology 39: 396-400.

189. Giavazzi R, Giuliani R, Coltrini D, Bani MR, Ferri C, et al. (2001) Modulation of tumor angiogenesis by conditional expression of fibroblast growth factor-2 affects early but not established tumors. Cancer Res 61: 309-317.

190.Lieu C, Heymach J, Overman M, Tran H, Kopetz S (2011) Beyond VEGF: inhibition of the fibroblast growth factor pathway and antiangiogenesis. Clin Cancer Res 17: 6130-6139. 
Citation: Khalid A, Javaid MA (2016) Fibroblast Growth Factors and their Emerging Cancer-Related Aspects. J Cancer Sci Ther 8: 190-205. doi:10.4172/1948-5956.1000413

191. Suri C, Jones PF, Patan S, Bartunkova S, Maisonpierre PC, et al. (1996) Requisite role of angiopoietin a ligand for the TIE2 receptor, during embryonic angiogenesis. Cell 87: 1171-1180.

192. Yancopoulos GD, Davis S, Gale NW, Rudge JS, Wiegand SJ, et al. (2000) Vascular-specific growth factors and blood vessel formation. Nature 407: 242 248.

193. Dieci MV, Arnedos M, Andre F, Soria JC (2013) Fibroblast growth factor receptor inhibitors as a cancer treatment: from a biologic rationale to medical perspectives. Cancer Discov 3: 264-279.

194. Crawford Y, Ferrara N (2009) Tumor and stromal pathways mediating refractoriness/resistance to anti-angiogenic therapies. Trends Pharmacol Sci 30: 624-630.

195. Ellis LM, Hicklin DJ (2008) Pathways mediating resistance to vascula endothelial growth factor-targeted therapy. Clin Cancer Res 14: 6371-6375.

196. Casanovas O, Hicklin DJ, Bergers G, Hanahan D (2005) Drug resistance by evasion of antiangiogenic targeting of VEGF signaling in late-stage pancreatic islet tumors. Cancer Cell 8: 299-309.

197. Ferrara N (2010) Pathways mediating VEGF-independent tumor angiogenesis. Cytokine Growth Factor Rev 21: 21-26.

198. Cross MJ, Claesson-Welsh L (2001) FGF and VEGF function in angiogenesis: signalling pathways, biological responses and therapeutic inhibition. Trends Pharmacol Sci 22: 201-207.

199. McMahon G (2000) VEGF receptor signaling in tumor angiogenesis. Oncologist 1: 3-10.

200. Rosen L (2000) Antiangiogenic strategies and agents in clinical trials Oncologist 1: 20-27.

201. Escudier B, Pluzanska A, Koralewski P, Ravaud A, Bracarda S, et al. (2007) Bevacizumab plus interferon alfa-2a for treatment of metastatic renal cell carcinoma: a randomised, double-blind phase III trial. Lancet 370: 2103-2111.

202. Garnier-Viougeat N, Rixe O, Paintaud G, Ternant D, Degenne D, et al. (2007) Pharmacokinetics of bevacizumab in haemodialysis. Nephrol Dial Transplant 22: 975.

203. Hurwitz H, Fehrenbacher L, Novotny W, Cartwright T, Hainsworth J, et al. (2004) Bevacizumab plus irinotecan, fluorouracil, and leucovorin for metastatic colorectal cancer. N Engl J Med 350: 2335-2342.

204. Kabbinavar F, Hurwitz HI, Fehrenbacher L, Meropol NJ, Novotny WF, et al. (2003) Phase II, randomized trial comparing bevacizumab plus fluorouracil (FU)/leucovorin (LV) with FU/LV alone in patients with metastatic colorectal cancer. J Clin Oncol 21: 60-65.

205. Bottsford-Miller JN, Coleman RL, Sood AK (2012) Resistance and escape from antiangiogenesis therapy: clinical implications and future strategies. J Clin Oncol 30: 4026-4034.

206. Willett CG, Duda DG, Di Tomaso E, Boucher Y, Ancukiewicz M, et al. (2009) Efficacy, safety, and biomarkers of neoadjuvant bevacizumab, radiation therapy, and fluorouracil in rectal cancer: a multidisciplinary phase II study. J Clin Oncol 27: 3020-3026.

207. Backer MV, Levashova Z, Patel V, Jehning BT, Claffey K, et al. (2007) Molecular imaging of VEGF receptors in angiogenic vasculature with singlechain VEGF-based probes. Nature medicine 13: 504-509.

208. Van TT, Hanibuchi M, Goto H, Kuramoto T, Yukishige S, et al. (2012) SU6668, a multiple tyrosine kinase inhibitor, inhibits progression of human malignant pleural mesothelioma in an orthotopic model. Respirology 17: 984-990.

209.Zhou S, Wang F, Hsieh TC, Wu JM, Wu E (2013) Thalidomide-a notorious sedative to a wonder anticancer drug. Curr Med Chem 20: 4102-4108.

210. Kasper B, Petersen F (2011) Molecular pathways of platelet factor 4/CXCL4 signaling. Eur J Cell Biol 90: 521-526.

211. Kowalska MA, Rauova L, Poncz M (2010) Role of the platelet chemokine platelet factor 4 (PF4) in hemostasis and thrombosis. Thromb Res 125: 292-296.

212. Slobbe $P$, Poot AJ, Windhorst AD, van Dongen GA (2012) PET imaging with small-molecule tyrosine kinase inhibitors: TKI-PET. Drug Discov Today 17 $1175-1187$.

213. Daniele G, Corral J, Molife LR, de Bono JS (2012) FGF receptor inhibitors: role in cancer therapy. Curr Oncol Rep 14: 111-119.
214. Liang G, Chen G, Wei X, Zhao Y, Li X (2013) Small molecule inhibition of fibroblast growth factor receptors in cancer. Cytokine Growth Factor Rev 24: 467-475.

215. Cheng A, Thongprasert S, Lim HY, Sukeepaisarnjaroen $W$, Yang $T$, et al. (2016) Randomized, open-label phase 2 study comparing frontline dovitinib versus sorafenib in patients with advanced hepatocellular carcinoma. Hepatology.

216. Dillon PM, Petroni GR, Moskaluk C, Fracasso PM, Douvas MG, et al. (2015) A phase II study of dovitinib in patients with recurrent or metastatic adenoid cystic carcinoma (ACC). ASCO Annual Meeting Proceedings 2015.

217. Hung HT, Ong R, Chow $P$ (2015) Dovitinib exerts potent antitumor effects in gastrointestinal stromal tumors. Cancer research 75: 795-795.

218. Kang CW, Jang KW, Sohn J, Kim SM, Pyo KH, et al. (2015) Antitumor Activity and Acquired Resistance Mechanism of Dovitinib (TKI258) in RETRearranged Lung Adenocarcinoma. Mol Cancer Ther 14: 2238-2248.

219. Konecny GE, Finkler N, Garcia AA, Lorusso D, Lee PS, et al. (2015) Secondline dovitinib (TKI258) in patients with FGFR2-mutated or FGFR2-non-mutated advanced or metastatic endometrial cancer: a non-randomised, open-label, two-group, two-stage, phase 2 study. Lancet Oncol 16: 686-694.

220. Kimes K, Beasley K, Dalton SR (2015) Eruptive milia and comedones during treatment with dovitinib. Dermatol Online J 21.

221. André F, Cortés J (2015) Rationale for targeting fibroblast growth factor receptor signaling in breast cancer. Breast Cancer Res Treat 150: 1-8.

222. Lewin J, Siu LL (2015) Development of Fibroblast Growth Factor Receptor Inhibitors: Kissing Frogs to Find a Prince? J Clin Oncol 33: 3372-3374.

223. Ursu A, Waldmann $\mathrm{H}$ (2015) Hide and seek: Identification and confirmation of small molecule protein targets. Bioorg Med Chem Lett 25: 3079-3086.

224. McCormack PL (2015) Nintedanib: first global approval. Drugs 75: 129-139.

225. Katoh M (2016) FGFR inhibitors: Effects on cancer cells, tumor microenvironment and whole-body homeostasis (Review). Int J Mol Med 38: 3-15.

226. Lu L, Saunders VA, Leclercq TM, Hughes TP, White DL (2015) Ponatinib is not transported by ABCB, ABCG2 or OCT-1 in CML cells. Leukemia 29: 17921794

227. Chan JK, Deng W, Higgins R, Bonebrake AJ, Hicks M, et al. (2015) A phases Il evaluation of brivanib in the treatment of persistent or recurrent carcinoma of the cervix: An NRG Oncology/Gynecologic Oncology Group study. ASCO Annual Meeting Proceedings 201: e16599.

228. Cicenas J, Cicenas E (2016) Multi-kinase inhibitors, AURKs and cancer. Med Oncol 33: 43

229. Heindryckx F, Gerwins $P$ (2015) Targeting the tumor stroma in hepatocellular carcinoma. World J Hepatol 7: 165-176.

230. Schlumberger M, Tahara M, Wirth LJ, Robinson B, Brose MS, et al. (2015) Lenvatinib versus placebo in radioiodine-refractory thyroid cancer. $N$ Engl J Med 372: 621-630.

231. Goke F, Franzen A, Hinz TK, Marek LA, Yoon P, et al. (2015) FGFR1 Expression Levels Predict BGJ398 Sensitivity of FGFR1-Dependent Head and Neck Squamous Cell Cancers. Clin Cancer Res 21: 4356-4364.

232. Pollock PM, Geng X, Bonazzi VF, Mahon C, Stephenson S, et al. (2015) Abstract B114: Combination of BGJ398 with either a pan-PI3K inhibitor or a specific PIK3CA inhibitor shows synergy in FGFR2 mutant endometrial cancer cell lines. Molecular Cancer Therapeutics 14: B114-B114.

233. Dieci MV, Andre F (2013) 7 Targeting the Fibroblast Growth Factor Receptor Pathway in Human Cancer. In: Giaccone G, Soria JG (Eds). Targeted Therapies in Oncology (2ndedn). CRC Press, US.

234. Gavine PR, Mooney L, Kilgour E, Thomas AP, Al-Kadhimi K, et al. (2012) AZD4547: an orally bioavailable, potent, and selective inhibitor of the fibroblas growth factor receptor tyrosine kinase family. Cancer research 72: 2045-2056.

235. González-Cao M, Rodón J, Karachaliou N, Sánchez J, Santarpia M, et al (2015) Other targeted drugs in melanoma. Ann Transl Med 3: 266.

236. Bai A, Meetze K, Vo NY, Kollipara S, Mazsa EK, et al. (2010) GP369, an FGFR2-IIIb-specific antibody, exhibits potent antitumor activity against human cancers driven by activated FGFR2 signaling. Cancer Res 70: 7630-7639.

237.Sun HD, Malabunga M, Tonra JR, Direnzo R, Carrick FE, et al. (2007) 
Citation: Khalid A, Javaid MA (2016) Fibroblast Growth Factors and their Emerging Cancer-Related Aspects. J Cancer Sci Ther 8: $190-205$. doi:10.4172/1948-5956.1000413

Monoclonal antibody antagonists of hypothalamic FGFR1 cause potent but reversible hypophagia and weight loss in rodents and monkeys. Am J Physiol Endocrinol Metab 292: E964-76.

238. Harding TC, Long L, Palencia S, Zhang H, Sadra A, et al. (2013) Blockade of nonhormonal fibroblast growth factors by FP-1039 inhibits growth of multiple types of cancer. Sci Transl Med 5: 178ra39.

239. Florea AM, Büsselberg D (2011) Cisplatin as an anti-tumor drug: cellular mechanisms of activity, drug resistance and induced side effects. Cancers (Basel) 3: 1351-1371.

240.Song S, Wientjes MG, Gan Y, Au JL (2000) Fibroblast growth factors: an epigenetic mechanism of broad spectrum resistance to anticancer drugs. Proc Natl Acad Sci U S A 97: 8658-8663.

241. Ware KE, Marshall ME, Heasley LR, Marek L, Hinz TK, et al. (2010) Rapidly acquired resistance to EGFR tyrosine kinase inhibitors in NSCLC cell lines through de-repression of FGFR2 and FGFR3 expression. PloS one 5: e14117.

242. Yadav V, Zhang X, Liu J, Estrem S, Li S, et al. (2012) Reactivation of mitogenactivated protein kinase (MAPK) pathway by FGF receptor 3 (FGFR3) Ras mediates resistance to vemurafenib in human B-RAF V600E mutant melanoma. J Biol Chem 287: 28087-28098.

243. Javidi-Sharifi N, Traer E, Martinez J, Gupta A, Taguchi T, et al. (2015) crosstalk between kit and fgfr 3 promotes gastrointestinal stromal tumor cell growth and drug resistance. Cancer Res 75: 880-891.

244. Abdi J, Chen G, Chang H (2013) Drug resistance in multiple myeloma: latest findings and new concepts on molecular mechanisms. Oncotarget 4: 2186-2207.

245. Turkington R, Longley D, Allen W, Stevenson L, McLaughlin K, et al. (2014) Fibroblast growth factor receptor 4 (FGFR4): a targetable regulator of drug resistance in colorectal cancer. Cell Death Dis 5: e1046. 